UNITED STATES DEPARTMENT OF THE INTERIOR GEOLOGICAL SURVEY

Geohydrologic and Dril1-Hole Data for Test We11 USW H-1, Adjacent to Nevada Test Site, Nye County, Nevada

by

F. E. Rush, William Thordarson, and Laura Bruckheimer

Open-File Report 83-141

1983 
UNITED STATES DEPARTMENT OF THE INTERIOR

JAMES G. WATT, Secretary

GEOLOGICAL SURVEY

Dallas L. Peck, Director

For additional information write to:

Chief, Nuclear Hydrology Program Water Resources Division, Central Region U.S. Geological Survey Box 25046, Mail Stop 416 Denver Federa1 Center Lakewood, Colorado 80225
Copies of this report can be purchased from:

Open-File Services Section Western Distribution Branch U.S. Geological Survey Box 25425, Federal Center Lakewood, Colorado 80225 (Telephone: [303] 234-5888) 


\section{CONTENTS}

Page

Abstract--

Introduction--

Drilling operations-_-_- 1

Lithologic sampling and well logging-_-_- 4

Lithologic log--_-_- 4

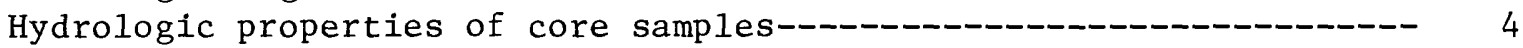

Geophysical well logs--_--_-_-_- 4

Hydrologic testing and water sampling-_-_-_-_- 12

Radioactive-tracer flow surveys-_-_-_-_ 12

Water levels-_-

Drilling-fluid use--_-_-_-_-_-_- 20

Pumping tests-- 20

Injection tests---_- 20

Chemical analyses of water-_an 20

Selected references--- 38

\section{ILLUSTRATIONS}

Figure 1. Map showing location of well USW H-1 in southern Nevada------ 2

2. Map showing location of well USW $\mathrm{H}-1$ and nearby geographic

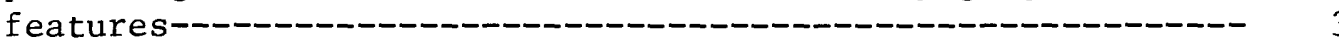

3. Chart showing generalized distribution of welding or induration in rocks penetrated by well USW H-1-_--_---

4-18. Graphs showing:

4. Radioactive-tracer flow survey for depth interval from 572 to 688 meters, showing percent of pumping rate produced by intervals-_-

5. Radioactive-tracer flow survey for depth interval from 687 to 1,829 meters, showing percent of pumping rate produced by intervals---

6. Drilling-fluid use and estimates of relative permeability-

7. Water-level drawdown data, pumping test 1 , depth interval from 572 to 688 meters---_--

8. Water-level recovery data, pumping test 1 , depth interval from 572 to 688 meters--

9. Water-level drawdown data, pumping test 2, depth interval from 687 to 1,829 meters----

10. Water-level recovery data, pumping test 2 , depth interval from 687 to 1,829 meters--

11. Water-level drawdown data, pumping test 3 , depth interval from 687 to 1,829 meters---

12. Water-level recovery data, pumping test 3 , depth interval from 687 to 1,829 meters--_-

13. Injection-test data for depth interval from 687 to 697

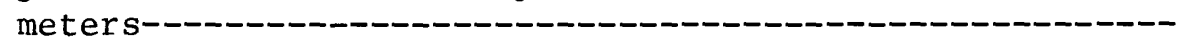




\section{ILLUSTRATIONS--Continued}

Figure 4-18. Graphs showing--Continued:

14. Injection-test data for depth interval from 811 to 1,829 meters- 31

15. Injection-test data for depth interval from 926 to 1,829 meters- 32

16. Injection-test data for depth interval from 1,200 to 1,829 meters 33

17. Injection-test data for depth interval from 1,407 to 1,829 meters- 34

18. Injection-test data for depth interval from 1,621 to 1,829 meters-

TABLES

Table 1. Bit and casing data-_ 4

2. Generalized lithologic log_a 5

3. Results of laboratory analyses of hydrologic properties of core samples from the unsaturated zone-_. 8

4. Results of laboratory analyses of hydrologic properties of core samples from the saturated zone-_. 9

5. Geophysical we11 logs run-_ 10

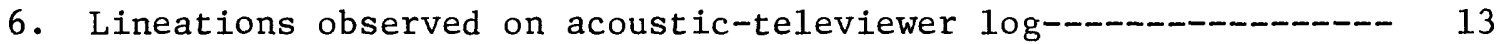

7. Distribution of out-of-gage hole-_ 14

8. Enlarged borehole intervals__ 15

9. Descriptions of water seeps above the zone of saturation-_-_-- 16

10. Water levels____ 19

11. Pumping-test data-__ 22

12. Injection-test data-__._. 29

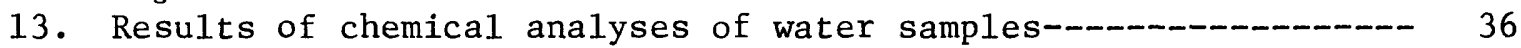


For those readers who prefer to use inch-pound rather than metric units, conversion factors for the terms used in this report are listed below:

\section{Metric unit}

centimeter $(\mathrm{cm})$

millimeter (mm)

kilometer $(\mathrm{km})$

cubic meter $\left(\mathrm{m}^{3}\right)$

meter (m)

degree Celsius $\left({ }^{\circ} \mathrm{C}\right)$

milligram per 1iter (mg/L)

microgram per liter $(\mu \mathrm{g} / \mathrm{L})$

liter per second (L/S)

1iter (L)
Multiply by

$3.937 \times 10^{-1}$

$3.937 \times 10^{-2}$

$6.214 \times 10^{-1}$

$3.531 \times 10^{1}$

3.281

$1.8^{\circ} \mathrm{C}+32$

$\underline{1 /} 1.0$

$\underline{1 /} 1.0$

$1.585 \times 10^{1}$

$2.642 \times 10^{-1}$
To obtain inch-pound unit

inch

inch

mile

cubic foot

foot

degree Fahrenheit

part per million

part per billion

gallon per minute

gallon

\section{1/ Approximate.}

National Geodetic Vertical Datum of 1929 (NGVD)--a geodetic datum derived from a general adjustment of the first-order level nets of both the United States and Canada, formerly called "Mean Sea Level"; it will be referred to as sea level in this report. 


\title{
GEOHYDROLOGIC AND DRILL-HOLE DATA FOR TEST WELL USW H-1, ADJACENT TO NEVADA TEST SITE, NYE COUNTY, NEVADA
}

By F. E. Rush, William Thordarson, and Laura Bruckheimer

\begin{abstract}
This report presents data collected to determine the hydraulic characteristics of rocks penetrated in test we11 USW H-1. The well is one of a series of test wells drilled in and near the southwestern part of the Nevada Test Site, Nye County, Nevada, in a program conducted on behalf of the U.S. Department of Energy. These investigations are part of the Nevada Nuclear Waste Storage Investigations to identify suitable sites for storage of high-level radioactive wastes. Data on drilling operations, 1ithology, borehole geophysics, hydrologic monitoring, core analysis, ground-water chemistry and pumping and injection tests for well USW $\mathrm{H}-1$ are contained in this report.
\end{abstract}

\section{INTRODUCTION}

The U.S. Geological Survey has been conducting investigations at Yucca Mountain, Nevada, to evaluate the hydrologic and geologic suitability of this site for storing high-level nuclear waste in an underground mined repository. The investigations are part of the Nevada Nuclear Waste Storage Investigations being conducted on behalf of the U.S. Department of Energy, Nevada Operations office. Test drilling has been a principal method of investigation. This report presents geohydrologic and drill-hole data from hydrologic test well USW $\mathrm{H}-1$. All data tables presented were compiled by the authors except where otherwise noted.

Test well USW H-1 is located in Nye County, Nevada, approximately $140 \mathrm{~km}$ northwest of Las Vegas in the southern part of the State (fig. 1). It is in an easterly-draining canyon of Yucca Mountain, northwest of Jackass Flats (fig. 2). Location of the site is Nevada State Coordinate System Central

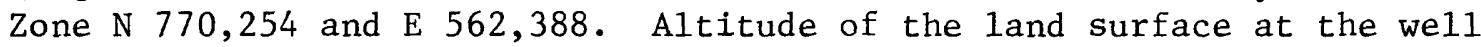
site is $1,302.2 \mathrm{~m}$ above sea level.

\section{DRILLING OPERATIONS}

Drilling of well USW H-1 started on September 2, 1980; total depth of $1,829 \mathrm{~m}$ was reached on November 22,1980 . The rotary-drilling fluid was air foam consisting of air, detergent, and water. We11 deviation was less than $3^{\circ}$ from the vertical. Bit and casing data are listed in table 1. Detailed drilling history is contained in the files of the drilling contractor Fenix and Scisson, Inc., Las Vegas, Nevada. 


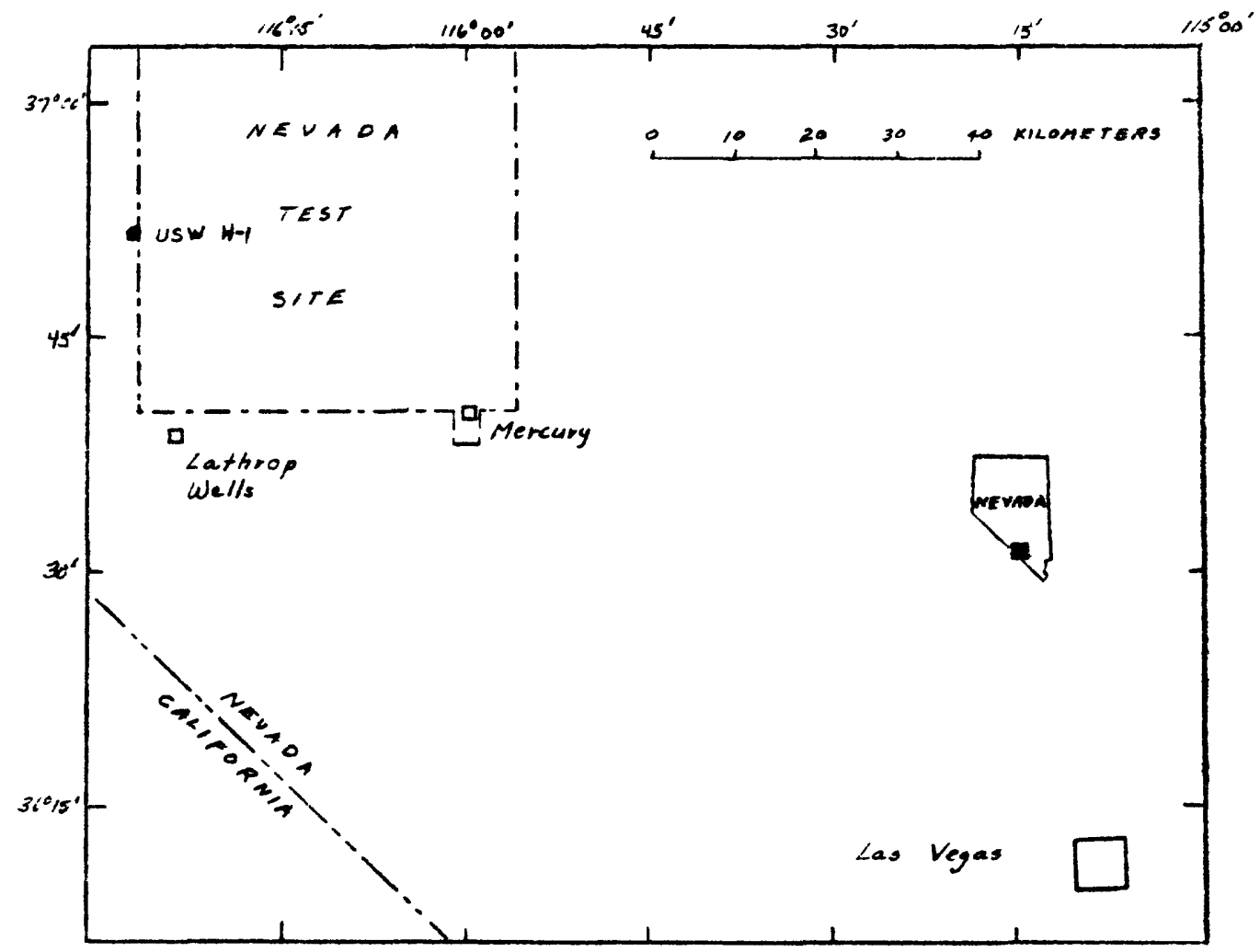

Figure 1.--Location of well USW H-1 in southern Nevada. 


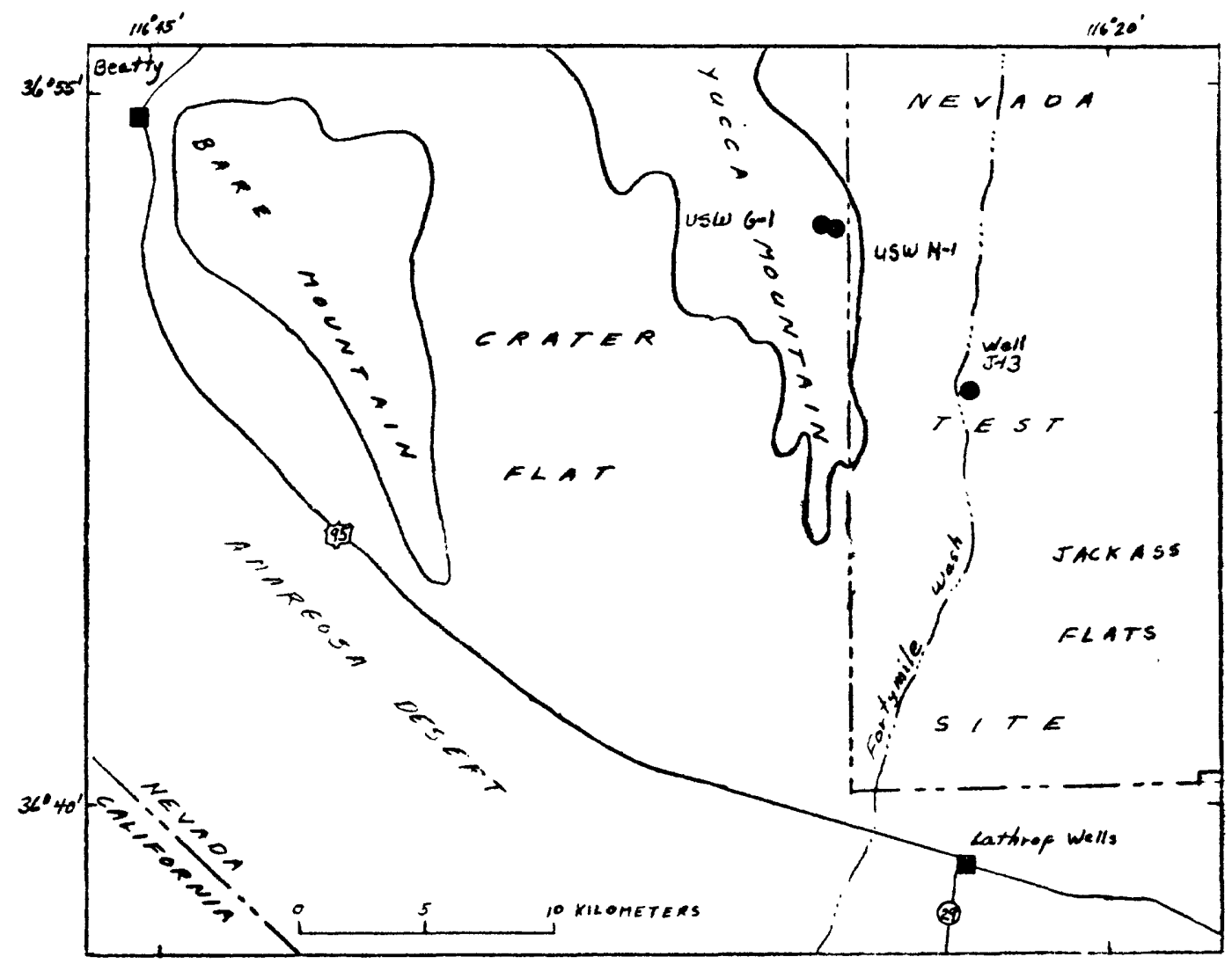

Figure 2.--Location of well USW $\mathrm{H}-1$ and nearby geographic features. 
Table 1.--Bit and casing data

\begin{tabular}{|c|c|c|c|c|}
\hline \multicolumn{2}{|c|}{$\begin{array}{l}\text { Drilled interval } \\
\text { (meters) }\end{array}$} & \multirow{2}{*}{$\begin{array}{c}\begin{array}{c}\text { Bit } \\
\text { diameter } \\
\text { (centimeters) }\end{array} \\
122\end{array}$} & $\begin{array}{l}\text { Cased interval } \\
\text { (meters) }\end{array}$ & \multirow{2}{*}{$\begin{array}{c}\begin{array}{c}\text { Casing inside } \\
\text { diameter } \\
\text { (centimeters) }\end{array} \\
---\end{array}$} \\
\hline 0 & 3 & & -- & \\
\hline 3 & 12 & 118 & $0-12$ & 76 \\
\hline 12 & 102 & 51 & $0-102$ & 41 \\
\hline 102 & 117 & 38 & -- & -- \\
\hline 117 & $-\quad 530$ & 34 & -- & -- \\
\hline 530 & $-\quad 688$ & 31 & $0-687$ & 23 \\
\hline 688 & $-1,829$ & 22 & $1 /$ & --- \\
\hline
\end{tabular}

\section{LITHOLOGIC SAMPLING AND WELL LOGGING}

\section{Lithologic Log}

The lithology penetrated by well USW $\mathrm{H}-1$, as determined by rock-bit cuttings and core, is shown in table 2. Ash-flow tuff is the predominant rock type in the section. A flow-breccia unit, $111 \mathrm{~m}$ thick, is the principal exception to the tuff sequence. Other exceptions are nine thin, poorly lithified, bedded or reworked tuffs at the base of most of the stratigraphic units, and within two of the units. The tuffs have various degrees of welding and induration, as summarized in figure 3. In the remainder of the report, shortened names of stratigraphic units are used; for the complete designation of formation and member, see table 2 .

\section{Hydrologic Properties of Core Samples}

Hydrologic analyses of 48 core samples of rocks from both unsaturated and saturated zones were made. All samples were analyzed for density, matrix porosity, pore saturation, and pore-water content. Horizontal- and verticalmatrix hydraulic conductivities were measured in samples from the saturated zone. Laboratory analysis of these cores is presented in tables 3 and 4 .

\section{Geophysical We11 Logs}

Several types of well logs were run in well USW H-1 to obtain useful information for designing the hydraulic tests and sampling programs. The types of logs and the intervals they included are listed in table 5 . 


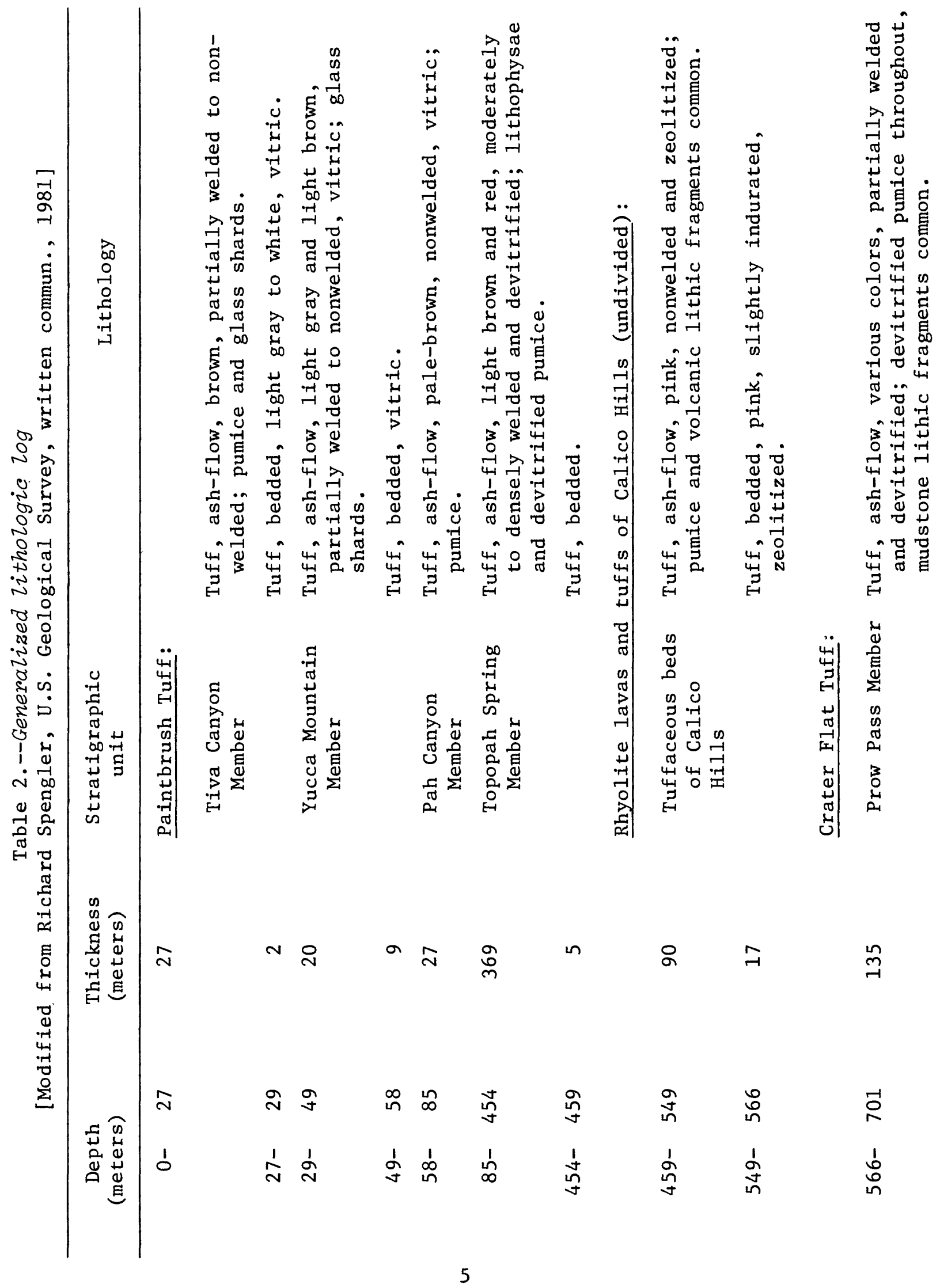




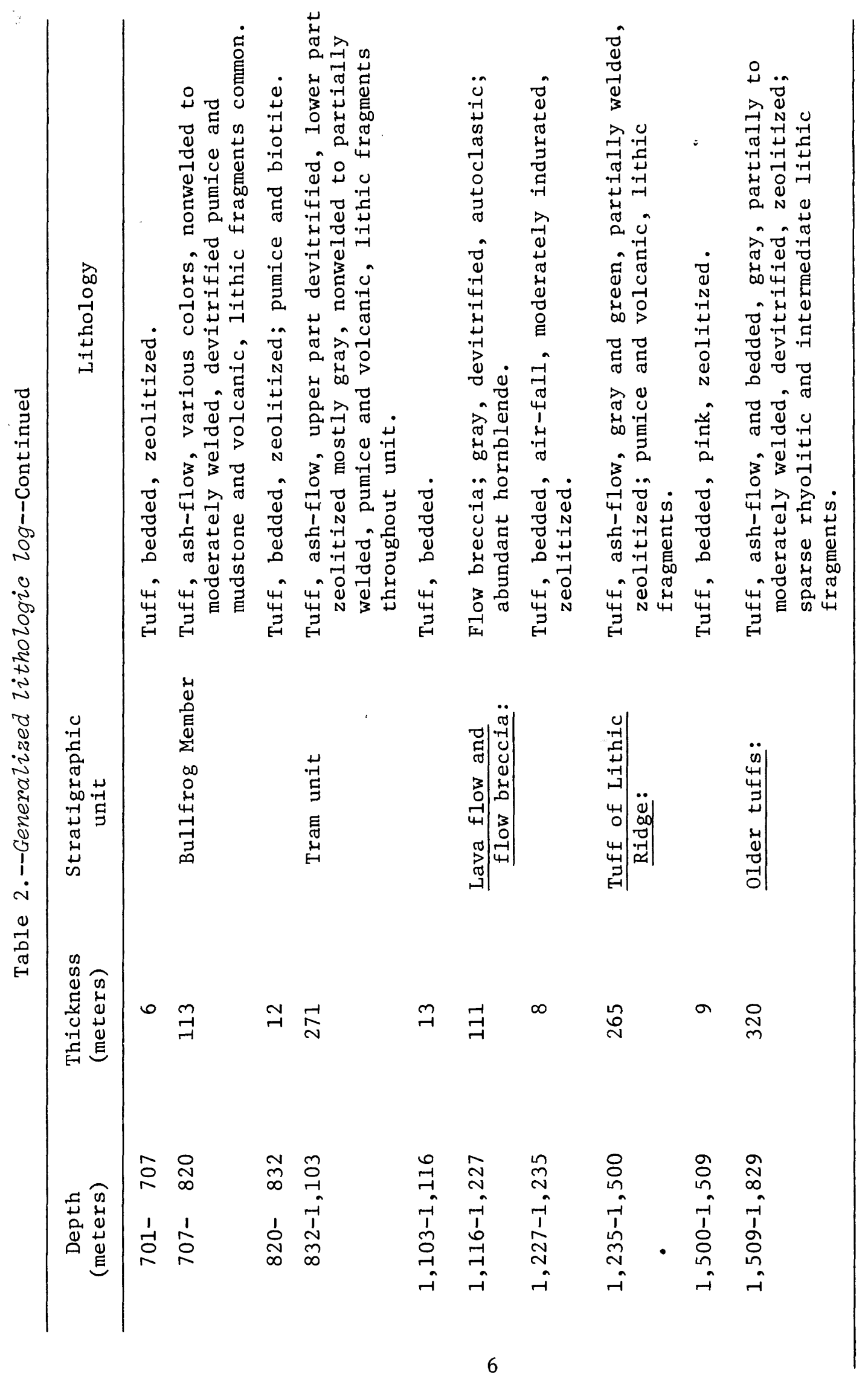




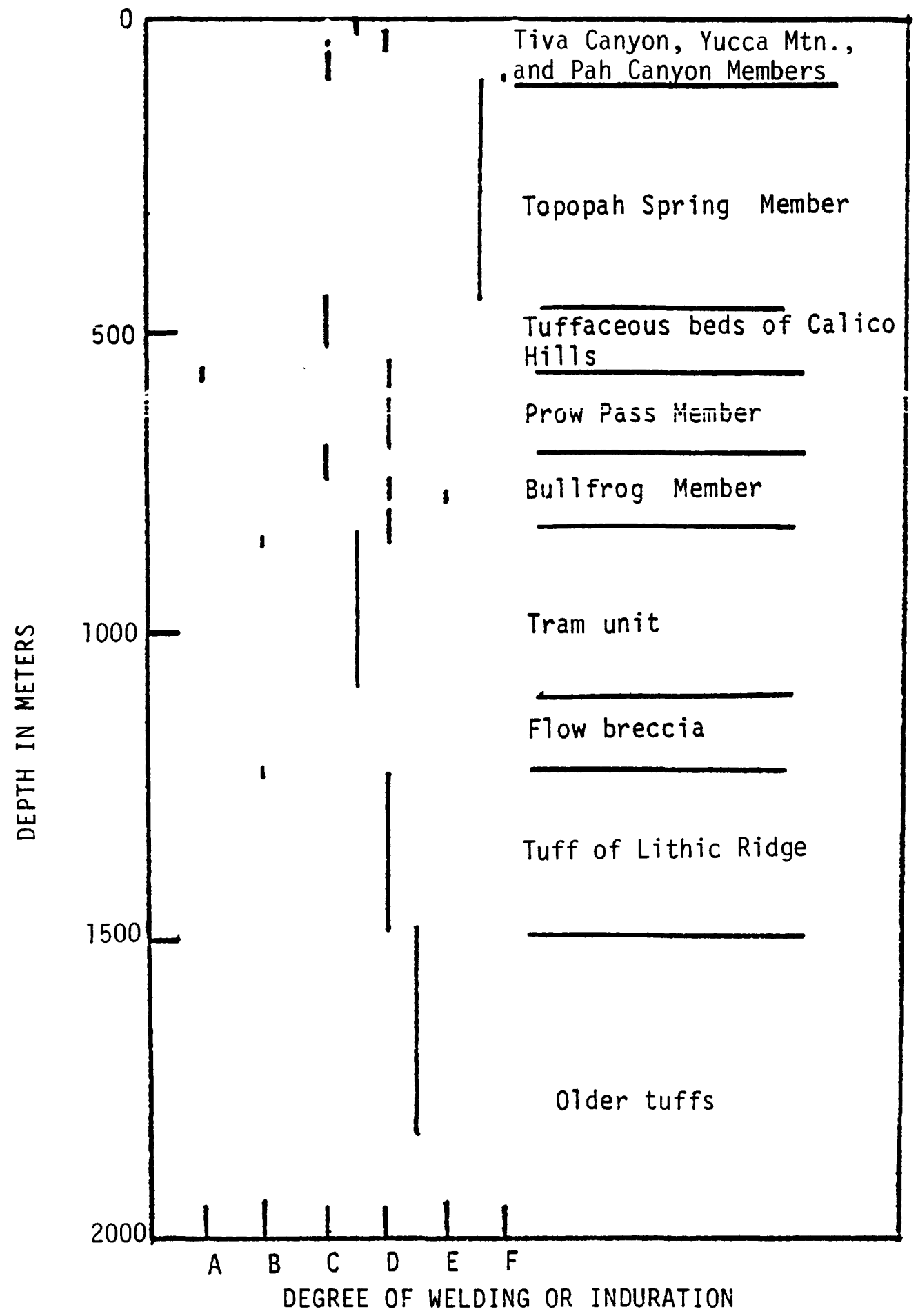

Figure 3.--Generalized distribution of welding and induration in rocks penetrated by well USW $\mathrm{H}-1$.

[Induration: A, slightly; B, moderately. Welding: $C$, nonwelded; $D$, partially; $E$, moderately; $F$, densely] 


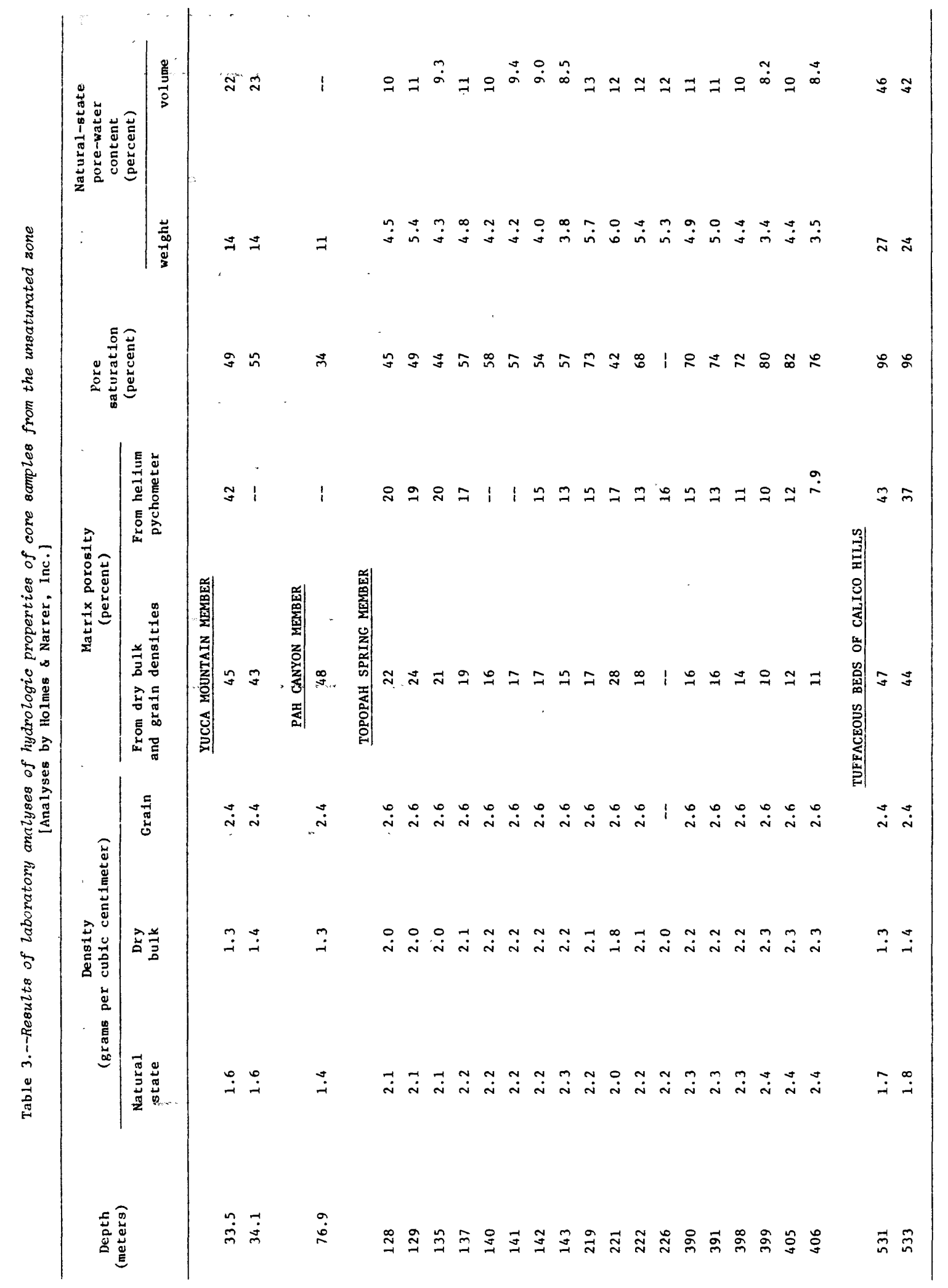




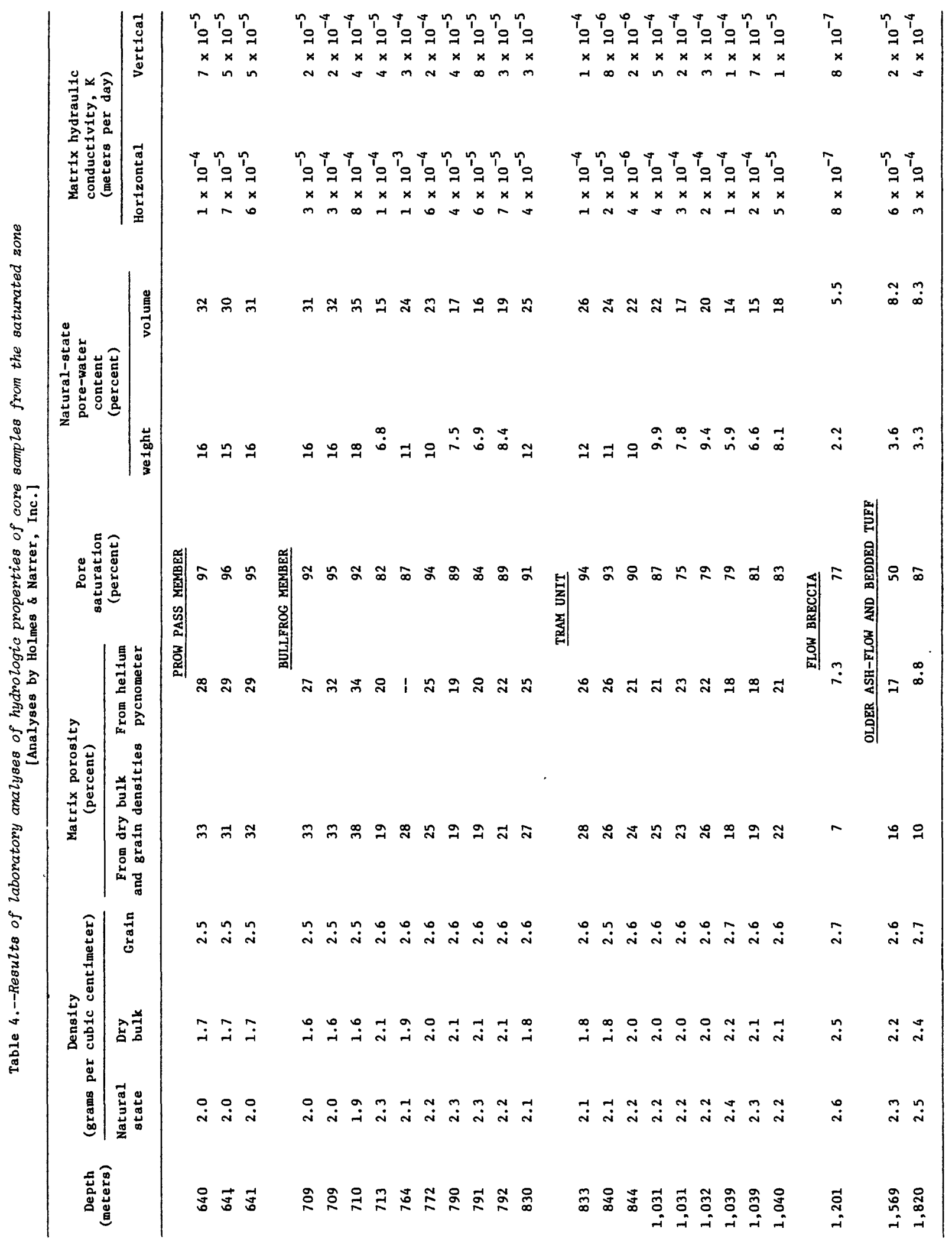


Table 5.--Geophysical well logs run

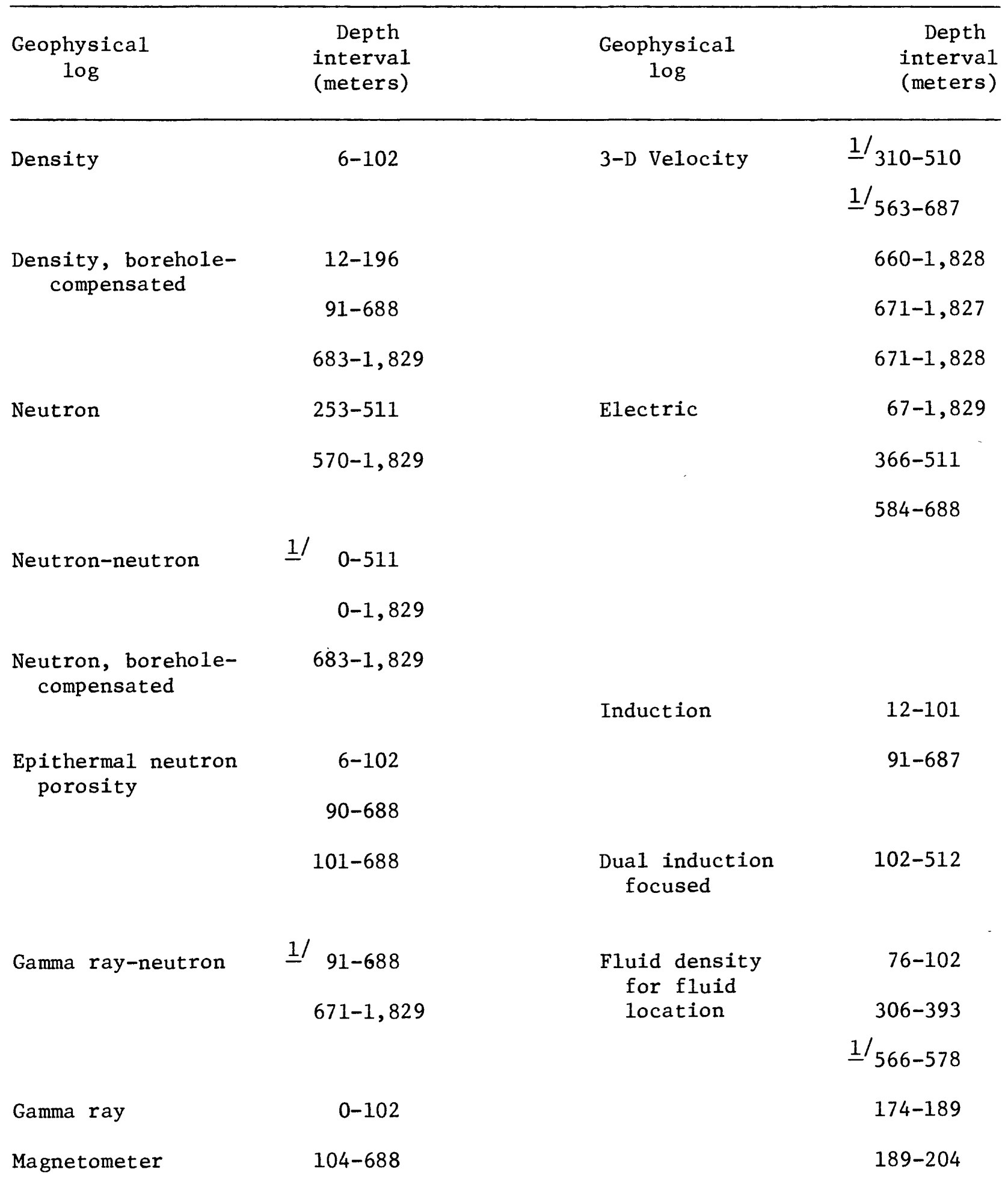


Table 5.--Geophysical well logs mu--Continued

\begin{tabular}{|c|c|c|c|}
\hline $\begin{array}{c}\text { Geophysical } \\
\text { log }\end{array}$ & $\begin{array}{c}\text { Depth } \\
\text { interval } \\
\text { (meters) }\end{array}$ & $\begin{array}{c}\text { Geophysical } \\
\text { log }\end{array}$ & $\begin{array}{c}\text { Depth } \\
\text { interva1 } \\
\text { (meters) }\end{array}$ \\
\hline \multirow{3}{*}{$\begin{array}{l}\text { Downhole seismic } \\
\text { survey }\end{array}$} & $107-685$ & & $152-167$ \\
\hline & $686-1,227$ & & $152-169$ \\
\hline & $1,227-1,821$ & & $549-565$ \\
\hline \multirow{2}{*}{$\begin{array}{l}\text { Nuclear annulus } \\
\text { investigation }\end{array}$} & $572-686$ & & $552-582$ \\
\hline & & & $\underline{2 /} 564-579$ \\
\hline \multirow[t]{2}{*}{ Temperature } & $0-688$ & & $\underline{3} / 522-583$ \\
\hline & $6-1,829$ & & $381-439$ \\
\hline \multirow[t]{5}{*}{ Caliper } & $0-99$ & & $351-427$ \\
\hline & & & $546-594$ \\
\hline & $85-688$ & & $564-576$ \\
\hline & $91-685$ & $\begin{array}{l}\text { Radioactive- } \\
\text { tracer survey }\end{array}$ & $102-688$ \\
\hline & $671-1,829$ & & $687-1,829$ \\
\hline Formation density & $0-102$ & Acoustic televiewer & $570-1,783$ \\
\hline \multirow{2}{*}{$\begin{array}{l}\text { Television-camera } \\
\text { videotape }\end{array}$} & $0-570$ & Gyroscopic & $0-1,783$ \\
\hline & & Spectral & $0-1,829$ \\
\hline
\end{tabular}

$1 /$ Two logs run in this interval.

2/ Five logs run in this interval.

3/ Six logs run in this interval. 
The acoustic televiewer $10 \mathrm{~g}$, an acoustic travel-time $10 \mathrm{~g}$, was made to record lithophysae and such linear features as fractures and bedding planes. Because the $\log$ was directionally oriented, inclined fractures and their attitude could be identified. Lineations observed in this $10 \mathrm{~g}$ are shown in table 6 .

Caliper logs were run to determine the open-hole diameter distribution with well depth. A summary of the hole gage is presented in table 7 . Out-ofgage is defined for this report as a diameter $100 \mathrm{~mm}$ greater than the diameter of the bit used to drill the interval. Thick out-of-gage intervals commonly cannot be tested by inflatable packers because of the difficulty of seating packers, or because over-inflation results in packer rupture. Enlarged borehole zones resulting from rock fracturing also were identified from caliper logs (table 8). These are zones having irregular enlargements of a smaller diameter than the out-of-gage zones.

A television-camera videotape was made to a depth of $687 \mathrm{~m}$ to observe open-hole conditions. A description of the water seeps observed at various intervals is given in table 9 . The source of water was not identified.

\section{HYDROLOGIC TESTING AND WATER SAMPLING}

\section{$\underline{\text { Radioactive-Tracer Flow Surveys }}$}

Radioactive-tracer flow surveys were run to measure vertical flow in the well while water was pumped into or out of the we11. The zones through which the water flowed were identified from this information. Surveys were made: (1) While the well was at a depth of $688 \mathrm{~m}$; and (2) after the well had been cased to a depth of $687 \mathrm{~m}$ and after drilling to total depth. Results of these surveys are shown in figures 4 and 5 .

\section{Water Levels}

Water-level observations and measurements in well USW $\mathrm{H}-1$ were made during and after the drilling as part of hydraulic tests, for the purpose of: (1) Locating any perched-water zones above the water table; (2) identifying the depth at which ground-water saturation occurs; (3) determining the composite hydraulic head in the well; and (4) identifying hydraulic heads in various water-bearing zones. Water-level measurements are listed in table 10.

After the composite water-level measurement made on June 24, 1982, piezometers were installed in the well to measure water levels in four widely spaced intervals. Intervals were selected to obtain information on the relative position of the hydraulic head. Preliminary data from the piezometers are included in table 10. 
Table 6.--Lineations observed on acoustic-televiewer log

[Log made in water-filled part of hole]

\begin{tabular}{|c|c|c|c|}
\hline Stratigraphic unit & $\begin{array}{l}\text { Depth below } \\
\text { land surface } \\
\text { (meters) }\end{array}$ & Orientation & $\begin{array}{c}\text { Remarks for } \\
\text { stratigraphic } \\
\text { unit }\end{array}$ \\
\hline \multirow[t]{6}{*}{ Prow Pass Member } & 580 & $\begin{array}{l}\text { Dipping steeply } \\
\text { westward }\end{array}$ & $\begin{array}{l}\text { Lineations present } \\
\text { throughout unit }\end{array}$ \\
\hline & 608 & $\begin{array}{l}\text { Dipping westward } \\
\text { about } 75^{\circ}\end{array}$ & \\
\hline & 635 & Horizontal & \\
\hline & 657 & Horizontal & \\
\hline & 676 & Horizontal & \\
\hline & 688 & Dipping westward & \\
\hline \multirow[t]{3}{*}{ Bullfrog Member } & 825 & Horizontal & ---- \\
\hline & 827 & Horizontal & \\
\hline & 831 & Horizontal & \\
\hline \multirow[t]{3}{*}{ Tram unit } & 874 & Horizontal & $\begin{array}{l}\text { Lineations only in } \\
\text { upper part of unit }\end{array}$ \\
\hline & 877 & $\begin{array}{l}\text { Dipping westward } \\
\text { about } 70^{\circ}\end{array}$ & \\
\hline & 919 & Horizontal & \\
\hline Flow breccia & 1,137 & $\begin{array}{l}\text { Dipping southeastward } \\
\text { about } 80^{\circ}\end{array}$ & $\begin{array}{l}\text { Lineations only in } \\
\text { upper part of unit }\end{array}$ \\
\hline \multirow[t]{3}{*}{ Older tuffs } & 1,635 & Horizontal & ----- \\
\hline & 1,636 & Horizontal & \\
\hline & 1,665 & Horizontal & \\
\hline
\end{tabular}


Table 7.--Distribution of out-of-gage hole

\begin{tabular}{|c|c|c|}
\hline Stratigraphic unit & $\begin{array}{l}\text { Part of unit } \\
\text { out of gage } \\
\text { (percent) }\end{array}$ & $\begin{array}{c}\text { Location within } \\
\text { stratigraphic } \\
\text { unit }\end{array}$ \\
\hline Tiva Canyon Member $\underline{1 /}$ & 39 & In lower part of interval \\
\hline Yucca Mountain Member & 26 & Mostly near base of unit \\
\hline Pah Canyon Member & 42 & Throughout unit \\
\hline Topopah Spring Member & 16 & Throughout unit \\
\hline $\begin{array}{l}\text { Tuffaceous beds of } \\
\text { Calico Hills }\end{array}$ & 13 & Near base of unit \\
\hline Prow Pass Member & 19 & In upper one-half of unit \\
\hline Bu11frog Member & 44 & In upper one-half of unit \\
\hline Tram unit & 0.1 & Near base of unit \\
\hline Flow breccia & 7 & Near base of unit \\
\hline Tuff of Lithic Ridge & 2 & In lower part of unit \\
\hline older tuffs & 4 & At mid-interval \\
\hline Average for well & 10 & \\
\hline
\end{tabular}

$1 /$ Below a depth of 12 meters. 
Table 8.--Enzarged borehole intervals

[Based on caliper-logs]

\begin{tabular}{|c|c|c|c|}
\hline Stratigraphic unit & $\begin{array}{l}\text { Depth interval } \\
\text { (meters) }\end{array}$ & $\begin{array}{l}\text { Interval } \\
\text { thickness } \\
\text { (meters) }\end{array}$ & $\begin{array}{l}\text { Remarks for } \\
\text { stratigraphic } \\
\text { unit }\end{array}$ \\
\hline Tiva Canyon Member & $1 / 12-29$ & 22 & $\begin{array}{l}\text { Interval continues into } \\
\text { underlying unit }\end{array}$ \\
\hline Yucca Mountain Member & $\begin{array}{r}29-34 \\
2 / \quad 44-58\end{array}$ & 30 & $\begin{array}{l}\text { Lower interval continues } \\
\text { into underlying unit }\end{array}$ \\
\hline Pah Canyon Member & $\begin{array}{l}58-74 \\
78-85\end{array}$ & 13 & \multirow[t]{2}{*}{$\begin{array}{l}\text { Lower interval continues } \\
\text { into underlying unit }\end{array}$} \\
\hline Topopah Spring Member & $\begin{array}{c}85-91 \\
123-139 \\
150-327 \\
332-406\end{array}$ & $\begin{array}{r}16 \\
177 \\
74\end{array}$ & \\
\hline $\begin{array}{l}\text { Tuffaceous beds of } \\
\text { Calico Hills }\end{array}$ & $-\cdots$ & -- & $\begin{array}{l}\text { No intervals identified } \\
\text { in stratigraphic unit }\end{array}$ \\
\hline Prow Pass Member & $-\cdots$ & 28 & $\begin{array}{l}\text { Ten zones occurring } \\
\text { throughout unit with a } \\
\text { combined thickness of } \\
28 \text { meters }\end{array}$ \\
\hline Bullfrog Member & $707-762$ & 55 & $\begin{array}{l}\text { Interval is upper one-half } \\
\text { of stratigraphic unit }\end{array}$ \\
\hline Tram unit & $-\cdots--$ & -- & $\begin{array}{l}\text { No intervals identified } \\
\text { in stratigraphic unit }\end{array}$ \\
\hline Flow breccia & $1,116-1,120$ & 4 & $\begin{array}{l}\text { Both intervals near top } \\
\text { of stratigraphic unit }\end{array}$ \\
\hline Tuff of Lithic Ridge & $-\cdots$ & $\cdots$ & $\begin{array}{l}\text { No intervals identified } \\
\text { in stratigraphic unit }\end{array}$ \\
\hline \multirow[t]{5}{*}{ Older tuffs } & $1,519-1,557$ & 38 & \multirow{5}{*}{$\begin{array}{l}\text { Enlargement may be the } \\
\text { result of little } \\
\text { lithification }\end{array}$} \\
\hline & $1,647-1,653$ & 6 & \\
\hline & $1,682-1,696$ & 14 & \\
\hline & $1,796-1,798$ & 2 & \\
\hline & $1,805-1,806$ & 1 & \\
\hline
\end{tabular}

1/ We11 cased to 12 meters.

$\underline{2}$ Interval includes a thin interval of bedded and reworked tuff. 
Table 9.--Descriptions of water seeps above the zone of saturation, observed with a down-hole television camera

[We11 cased to 102 meters]

\begin{tabular}{|c|c|}
\hline $\begin{array}{l}\text { Depth } \\
\text { (meters) }\end{array}$ & Description \\
\hline & Topopah Spring Member \\
\hline 183 & Rough walls; a few drops of water \\
\hline 261 & Vertical fracture seeping water \\
\hline $343-344$ & Extensively fractured, hole enlarged; water \\
\hline \multirow[t]{2}{*}{$351-358$} & Fracture seeping water; hole enlarged \\
\hline & Tuffaceous beds of Calico Hills \\
\hline $472-488$ & Lithic-rich tuff dripping small stream of water \\
\hline $488-495$ & $\begin{array}{l}\text { Lithic-rich tuff yielding water running down side } \\
\text { of hole }\end{array}$ \\
\hline $500-511$ & Stratiform beds dripping water \\
\hline $511-526$ & Lithic-rich tuff dripping water \\
\hline $526-533$ & Lithic-rich tuff yielding small stream of water \\
\hline $541-549$ & A few fractures; dripping water \\
\hline $549-566$ & Water on side of hole \\
\hline \multirow[t]{2}{*}{$564-566$} & Hole enlarged; dripping water \\
\hline & Prow Pass Member \\
\hline $566-570$ & Dripping water \\
\hline 570 & Large stream of water on side of hole \\
\hline
\end{tabular}




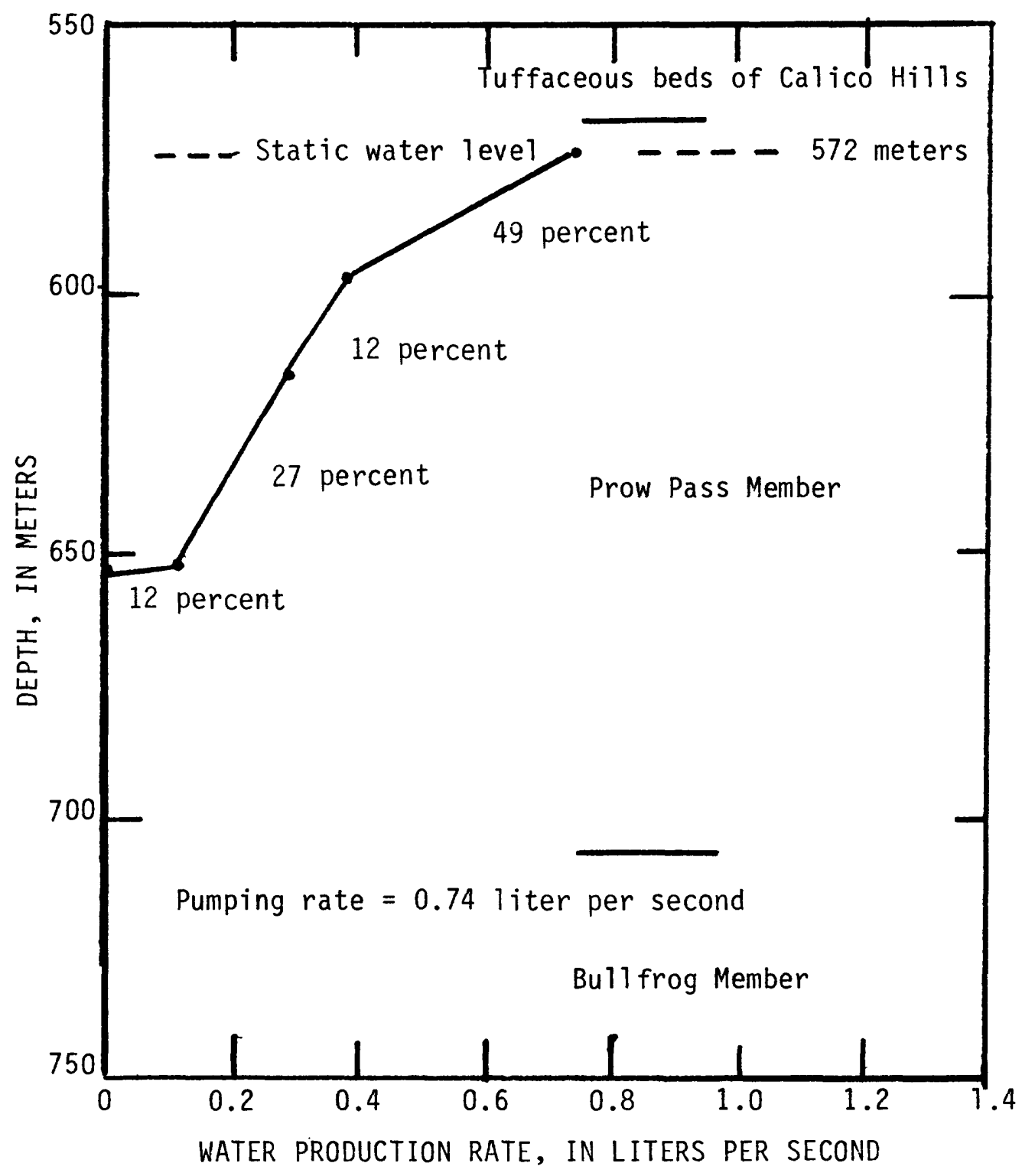

Figure 4.--Radioactive-tracer flow survey for depth interval from 572 to 688 meters, showing percent of pumping rate produced by intervals. 


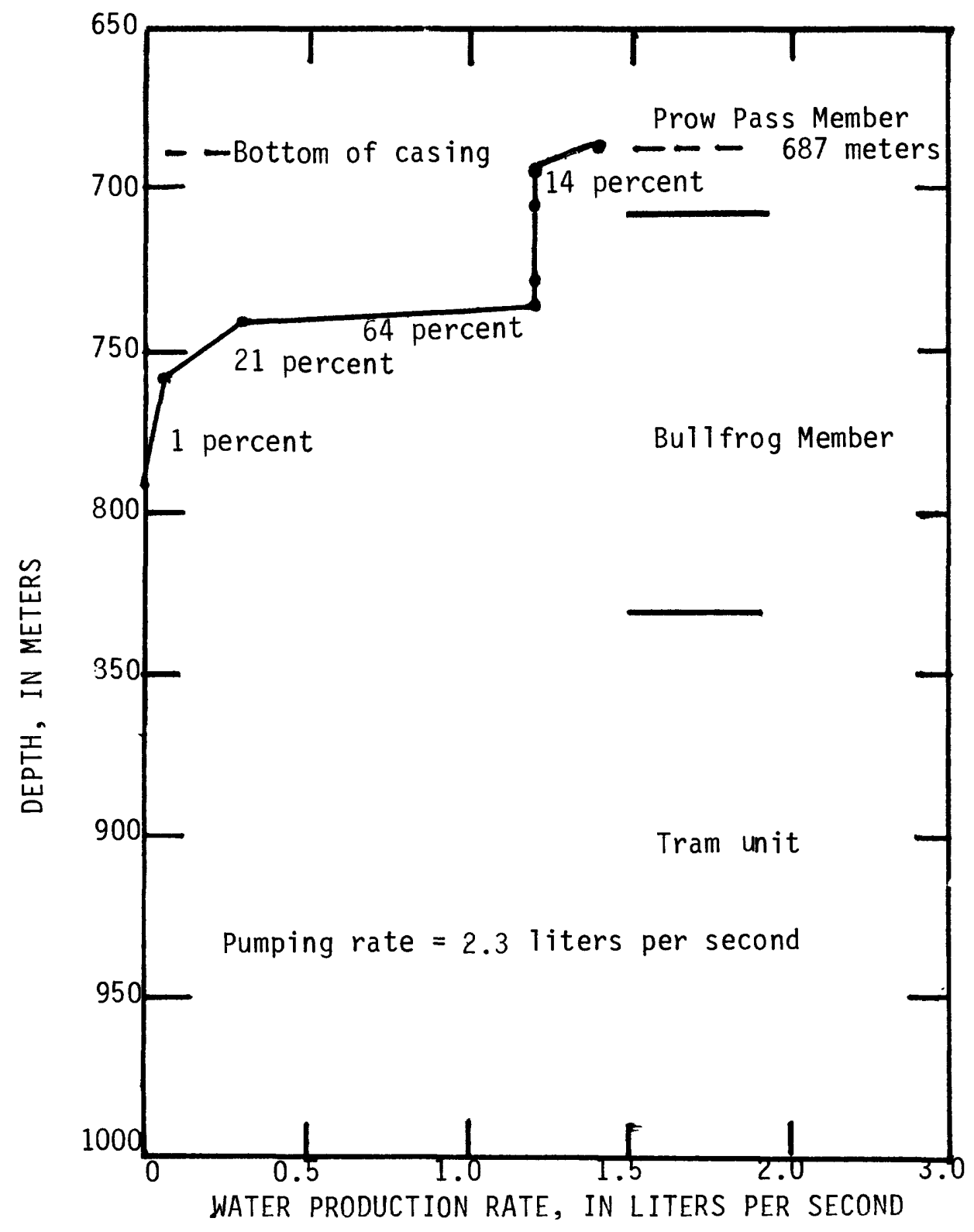

Figure 5.--Radioactive-tracer flow survey for depth interval from 687 to 1,829 meters, showing percent of pumping rate produced by intervals. 


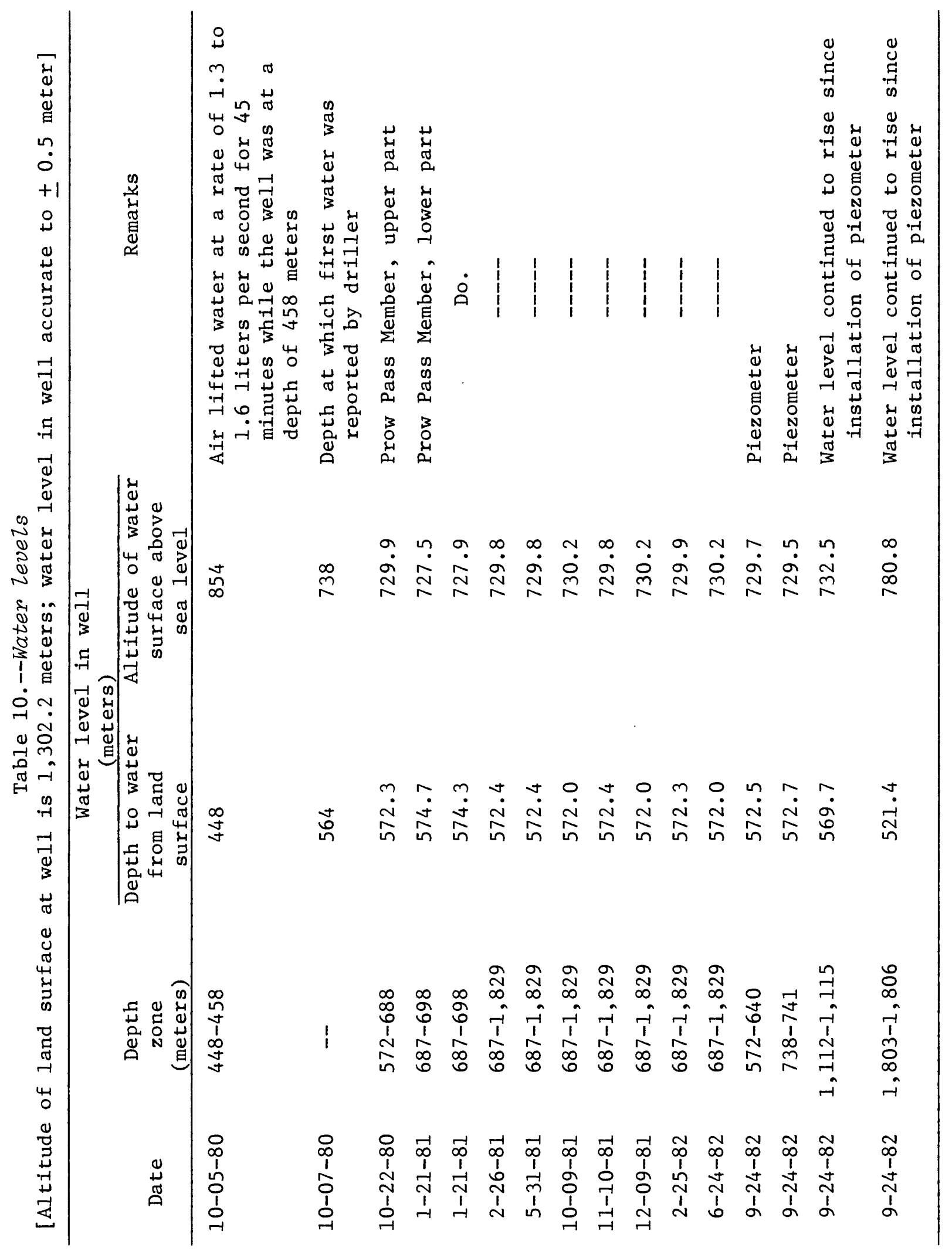




\section{Drilling-Fluid Use}

To minimize the invasion and plugging of fracture and matrix porosity while drilling the well, a drilling fluid of air-foam, consisting of small volumes of detergent and water and large volumes of air, was used. Approximately 14,300 L of detergent and 2,200,000 L of water were used during drilling. Variations in fluid use were recorded and are shown in figure 6 . Fluid-use rate while drilling was used as an approximate index of permeability, because more permeable zones receive more infiltration and, thus, less drilling fluid, than less permeable zones. In figure 6, horizontal offsets at $400 \mathrm{~m}, 680 \mathrm{~m}$, and $1,180 \mathrm{~m}$ correspond to periods when no drilling was in progress, rather than to fluid losses.

\section{Pumping Tests}

Drawdown and recovery tests were made in conjunction with two pumping periods: (1) At a depth of $688 \mathrm{~m}$ before casing was set, and (2) after the well had been cased to $687 \mathrm{~m}$ and drilled to a depth of $1,829 \mathrm{~m}$. Pumping-test information for these intervals is presented in table 11. Data are given for one set of tests for the upper interval and two sets of tests for the lower interval. Data plots of these tests are shown in figures 7 through 12 .

Drawdown-test data were plotted using drawdown versus time after start of pumping as the coordinates. Recovery-test data were plotted with residual drawdown (recovery) against time after pumping stopped as the coordinates.

\section{Injection Tests}

Injection tests were made using inflatable packers to isolate test zones. Intervals tested are shown in table 12. Data for six injection tests for the intervals between 687 and $1,829 \mathrm{~m}$ (total depth) are plotted in figures 13 through 18. The ratio of hydraulic head at a given time to initial hydraulic head is plotted against time since injection began.

\section{Chemical Analyses of Water}

Water samples were collected for chemical analyses near the end of pumping tests from depth intervals from 572 to $688 \mathrm{~m}$ and from 687 to $1,829 \mathrm{~m}$. The chemical constituents found in the samples are shown in table 13. Carbon-14 determination indicates that the apparent age of the ground water is about 12,000 to 13,000 years before present. 


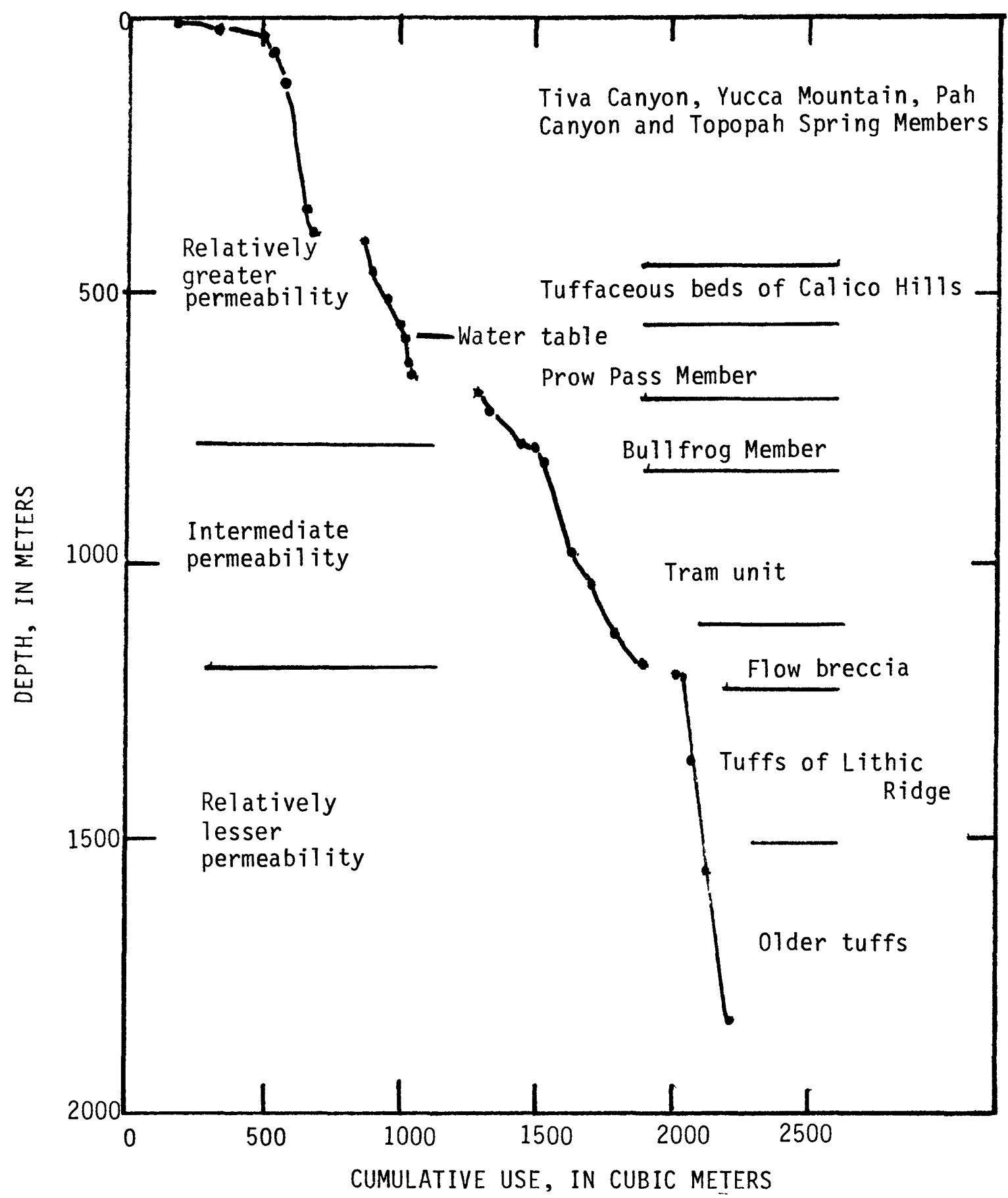

Figure 6.--Drilling-fluid use and estimates of relative permeability. 
Table 11.--Pumping-test data

\begin{tabular}{|c|c|c|c|c|}
\hline $\begin{array}{l}\text { Test } \\
\text { interval } \\
\text { (meters) }\end{array}$ & $\begin{array}{c}\text { Stratigraphic unit (s) } \\
\text { tested }\end{array}$ & $\begin{array}{l}\text { Type } \\
\text { of } \\
\text { test }\end{array}$ & $\begin{array}{l}\text { Pumping } \\
\text { rate, Q } \\
\text { (1iters } \\
\text { per } \\
\text { second) }\end{array}$ & $\begin{array}{l}\text { Pumping } \\
\text { period, } t \\
\text { (minutes) }\end{array}$ \\
\hline $572-688$ & Prow Pass Member & Drawdown & 3.4 & 2,880 \\
\hline $572-688$ & Prow Pass Member & Recovery & $1 / 3.4$ & $1 / 2,880$ \\
\hline $687-1,829$ & $\begin{array}{l}\text { Prow Pass Member and } \\
\text { underlying } \\
\text { penetrated units }\end{array}$ & Drawdown & 2.3 & 3,383 \\
\hline $687-1,829$ & do. & Recovery & $1 / 2.3$ & $1 / 3,383$ \\
\hline $687-1,829$ & do. & Drawdown & 3.1 & 90 \\
\hline $687-1,829$ & do. & Recovery & $\underline{1} / 3.1$ & $\underline{1 /}$ \\
\hline
\end{tabular}

$1 /$ For pumping prior to recovery test. 


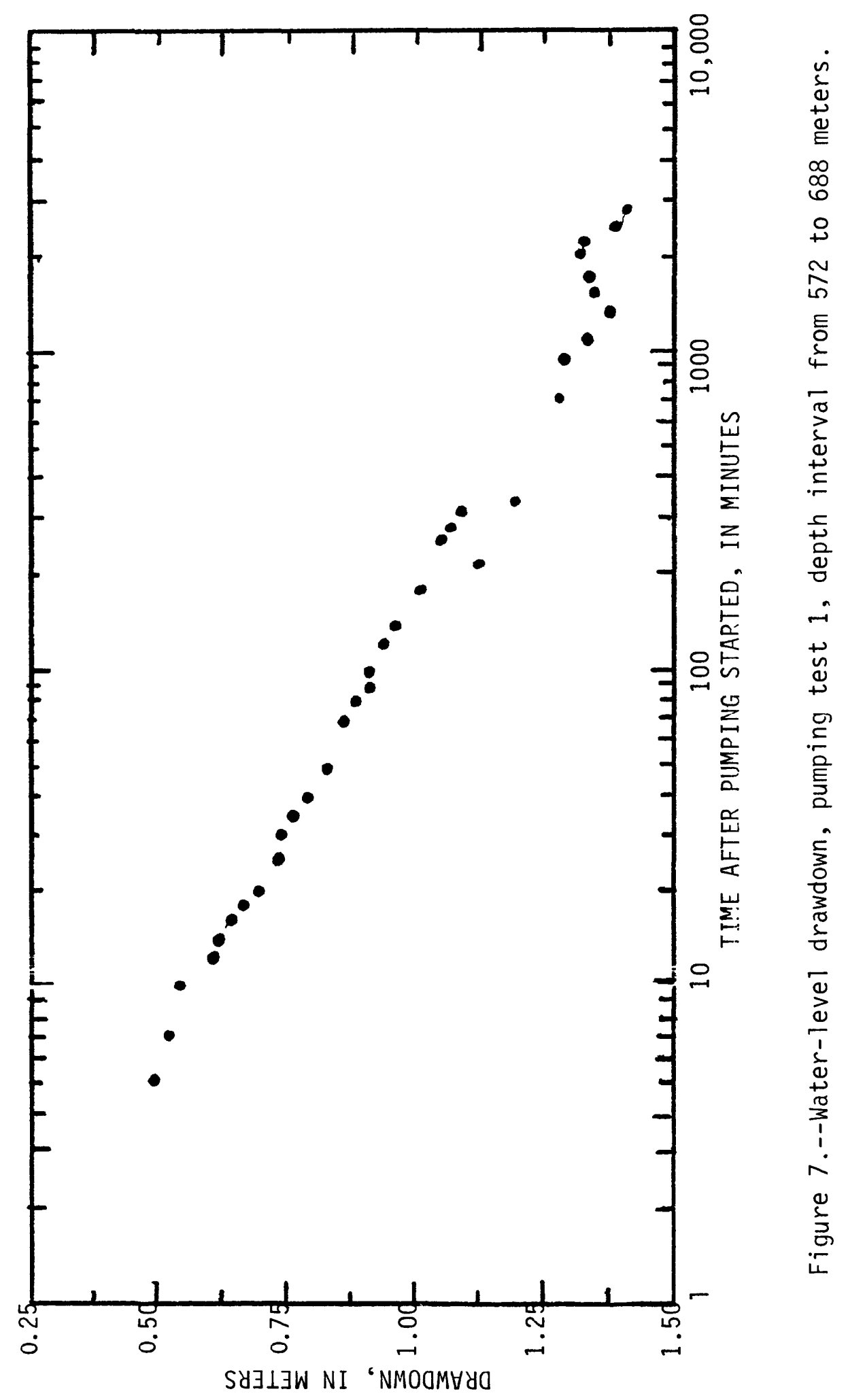




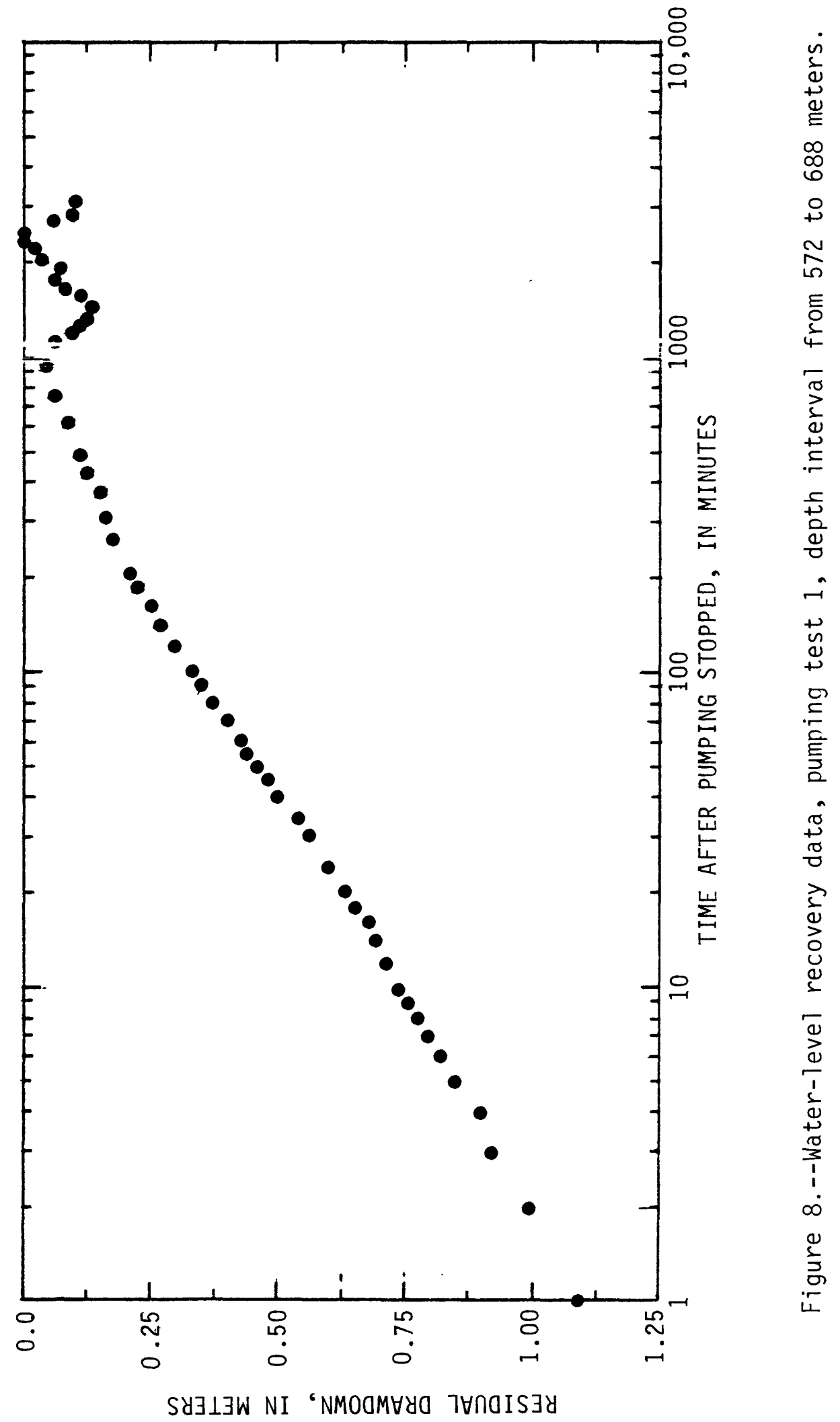




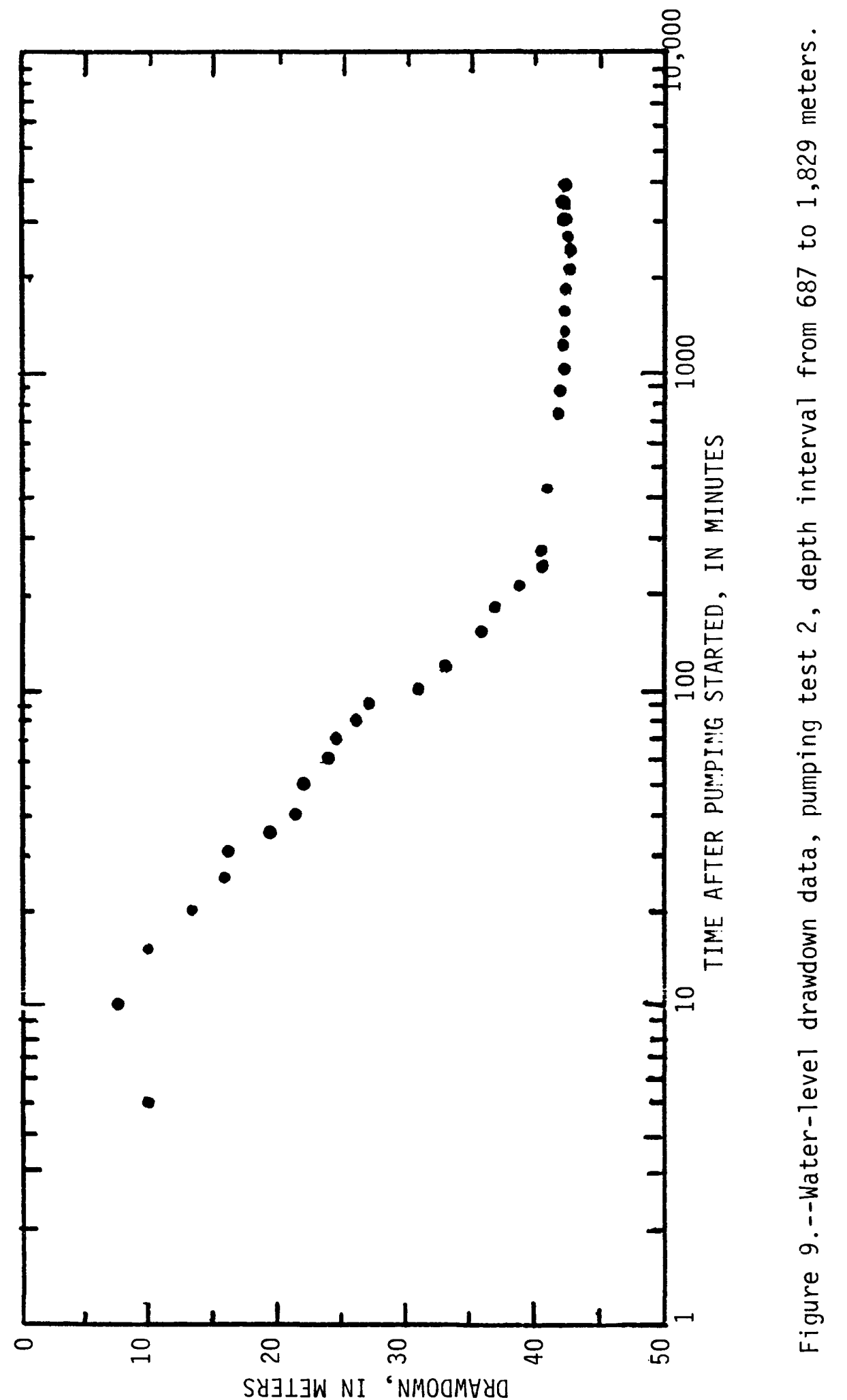




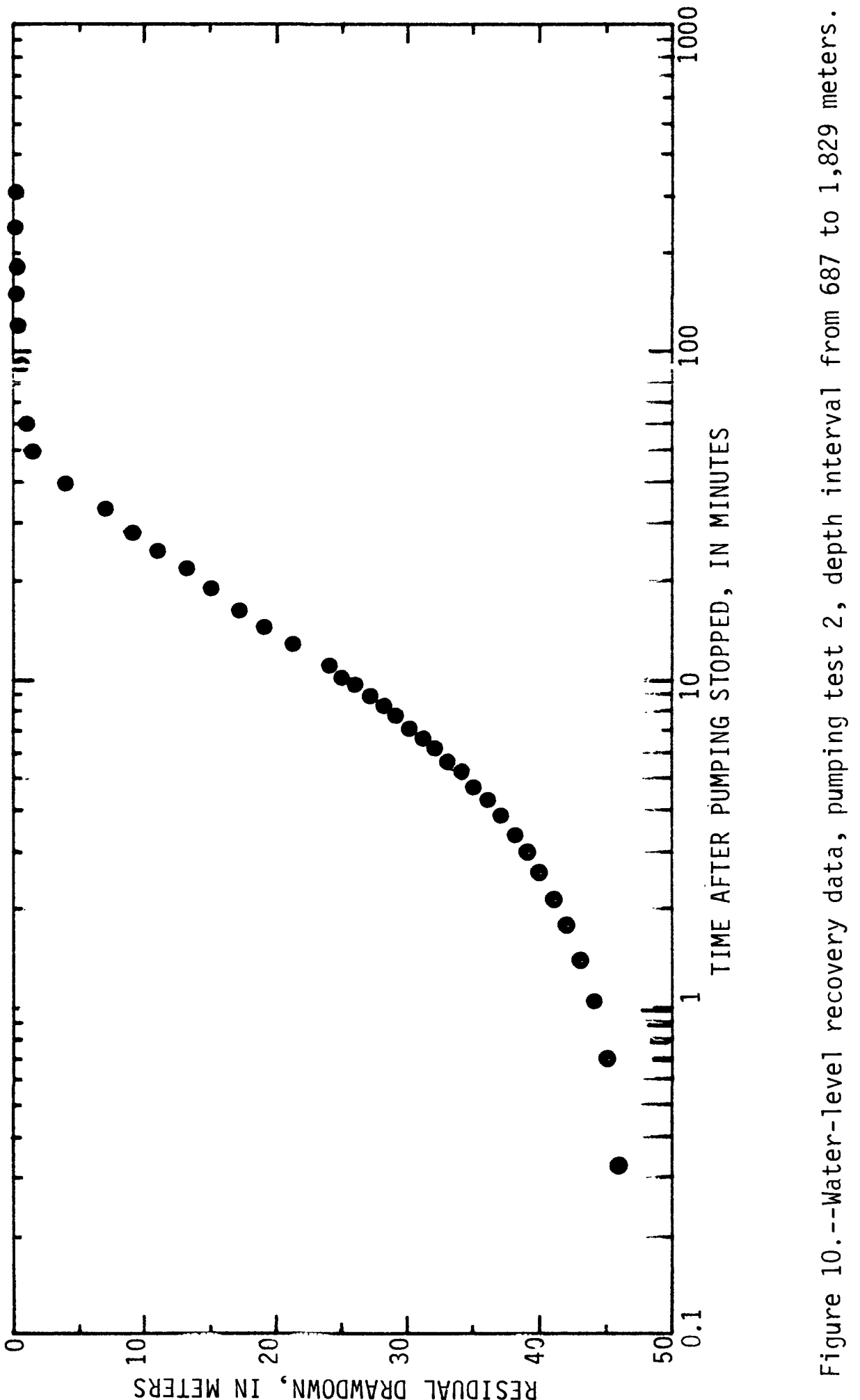




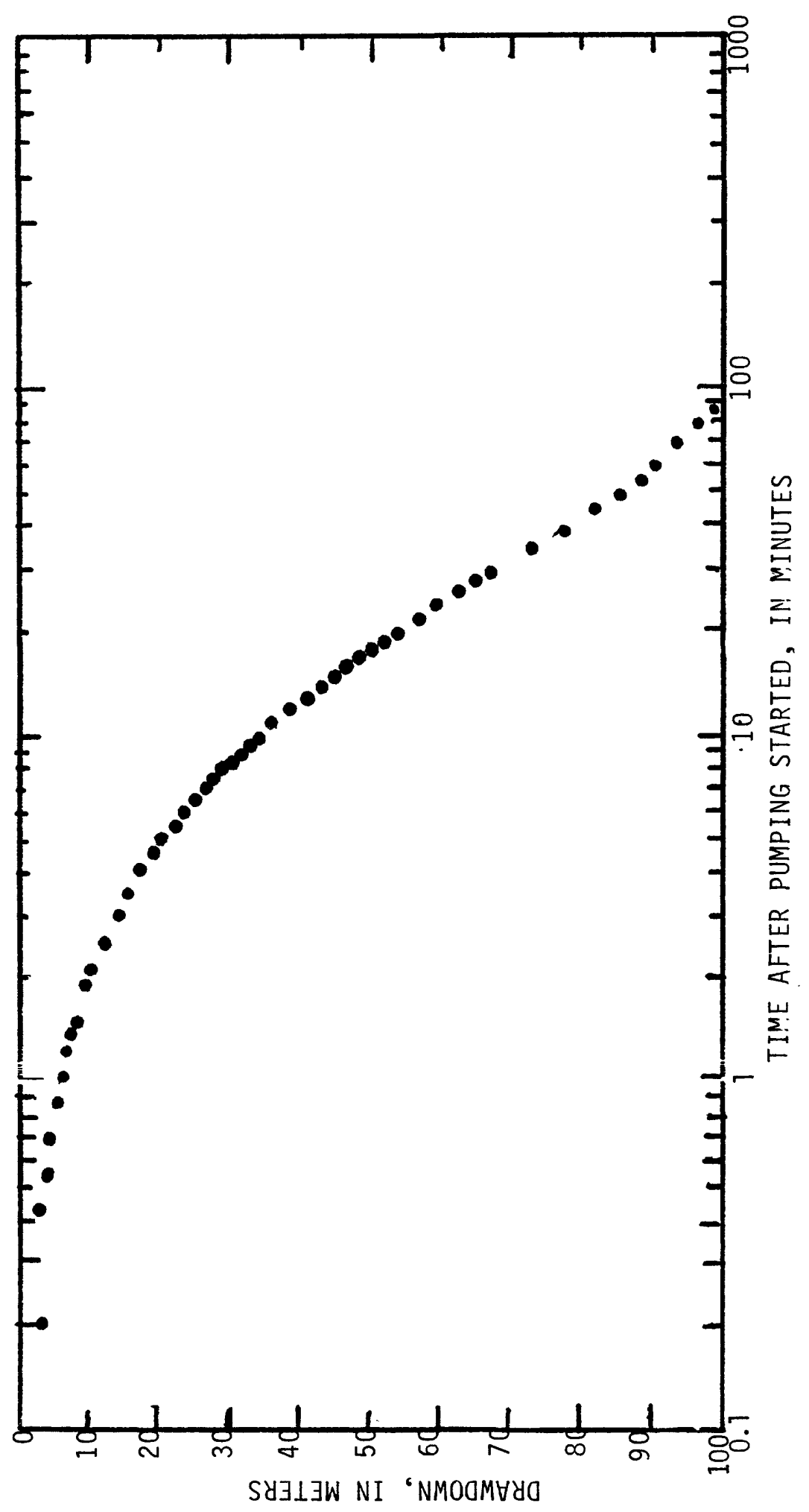

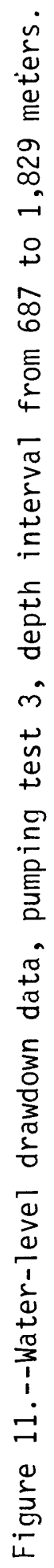

SYJLJW NI "NMOOMHYO 


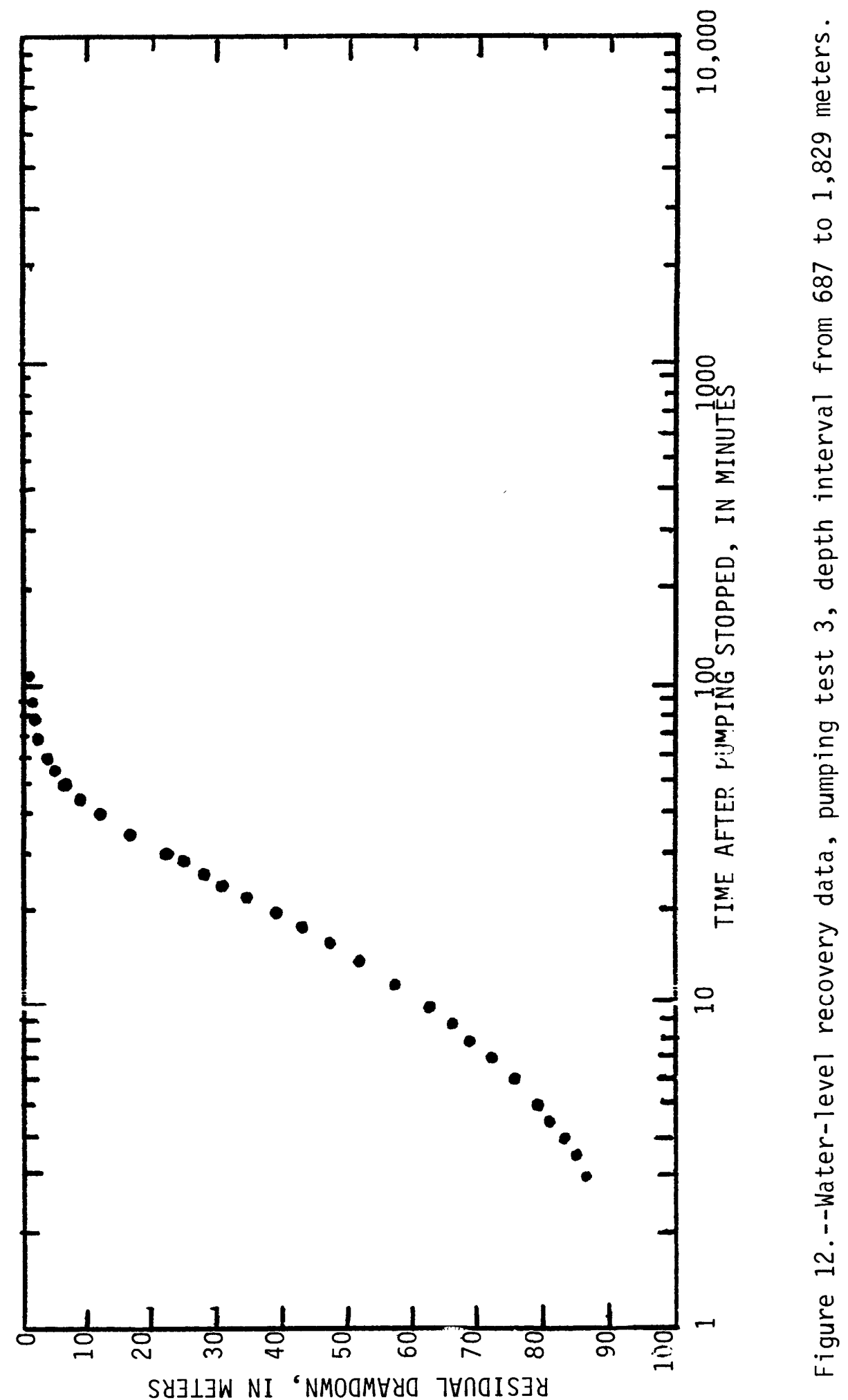


Table 12.--Injection-test data

\begin{tabular}{ccc}
\hline $\begin{array}{c}\text { Test interval } \\
\text { (meters) }\end{array}$ & $\begin{array}{c}\text { Stratigraphic unit (s) } \\
\text { tested }\end{array}$ & $\begin{array}{c}\text { Length of injection } \\
\text { period } \\
\text { (minutes) }\end{array}$ \\
\hline $687-697$ & Prow Pass Member & 60 \\
$811-1,829$ & $\begin{array}{c}\text { Bullfrog Member and } \\
\text { underlying penetrated units }\end{array}$ & 910 \\
$926-1,829$ & $\begin{array}{c}\text { Tram unit and underlying } \\
\text { penetrated units } \\
1,200-1,829\end{array}$ & 334 \\
$1,407-1,829$ & $\begin{array}{c}\text { Flow breccia and underlying } \\
\text { penetrated units } \\
\text { Tuff of Lithic Ridge } \\
\text { and older tuffs }\end{array}$ & 198 \\
$1,621-1,829$ & older tuffs & 350 \\
\hline
\end{tabular}




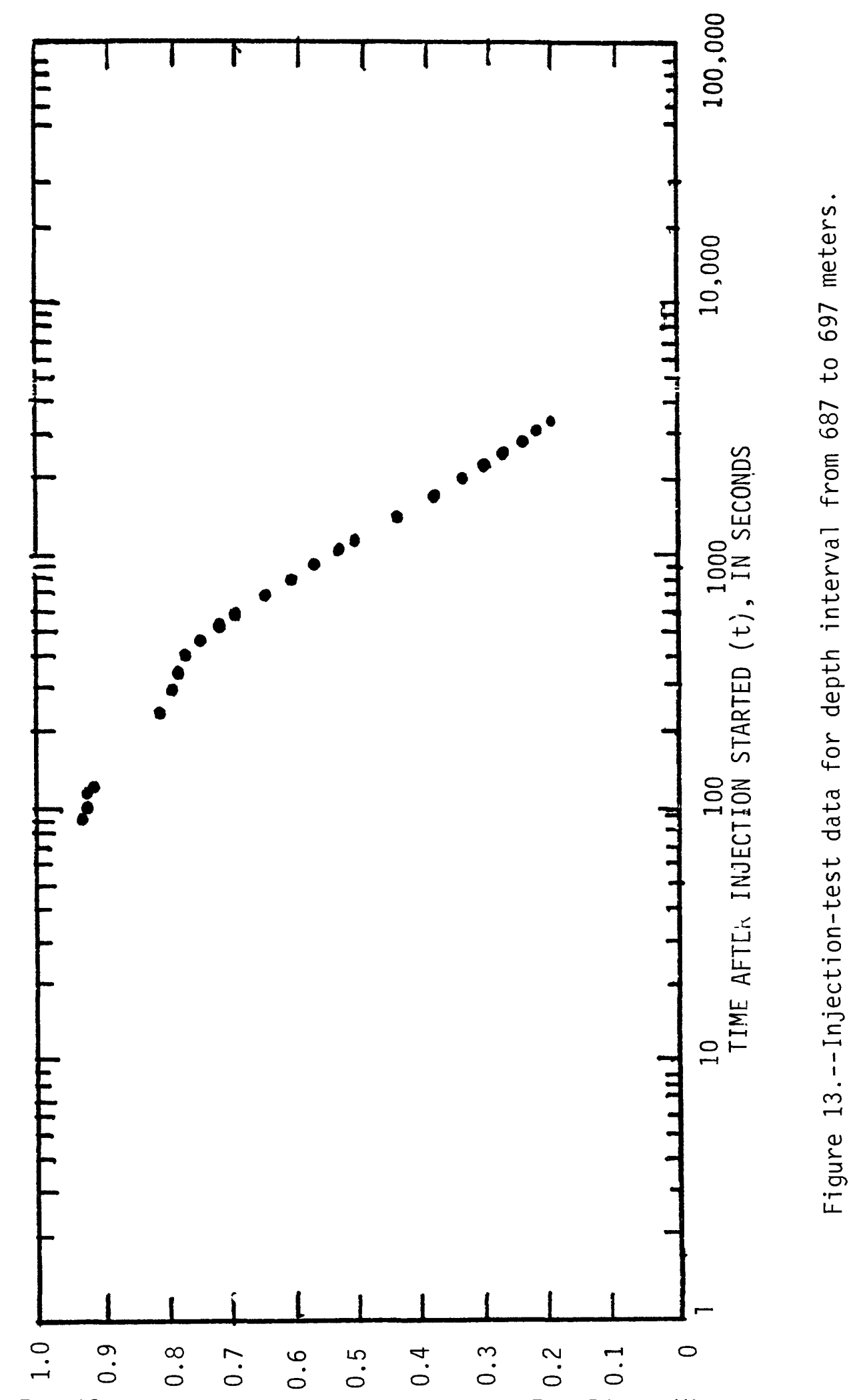

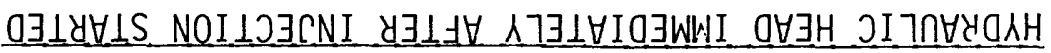

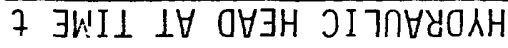




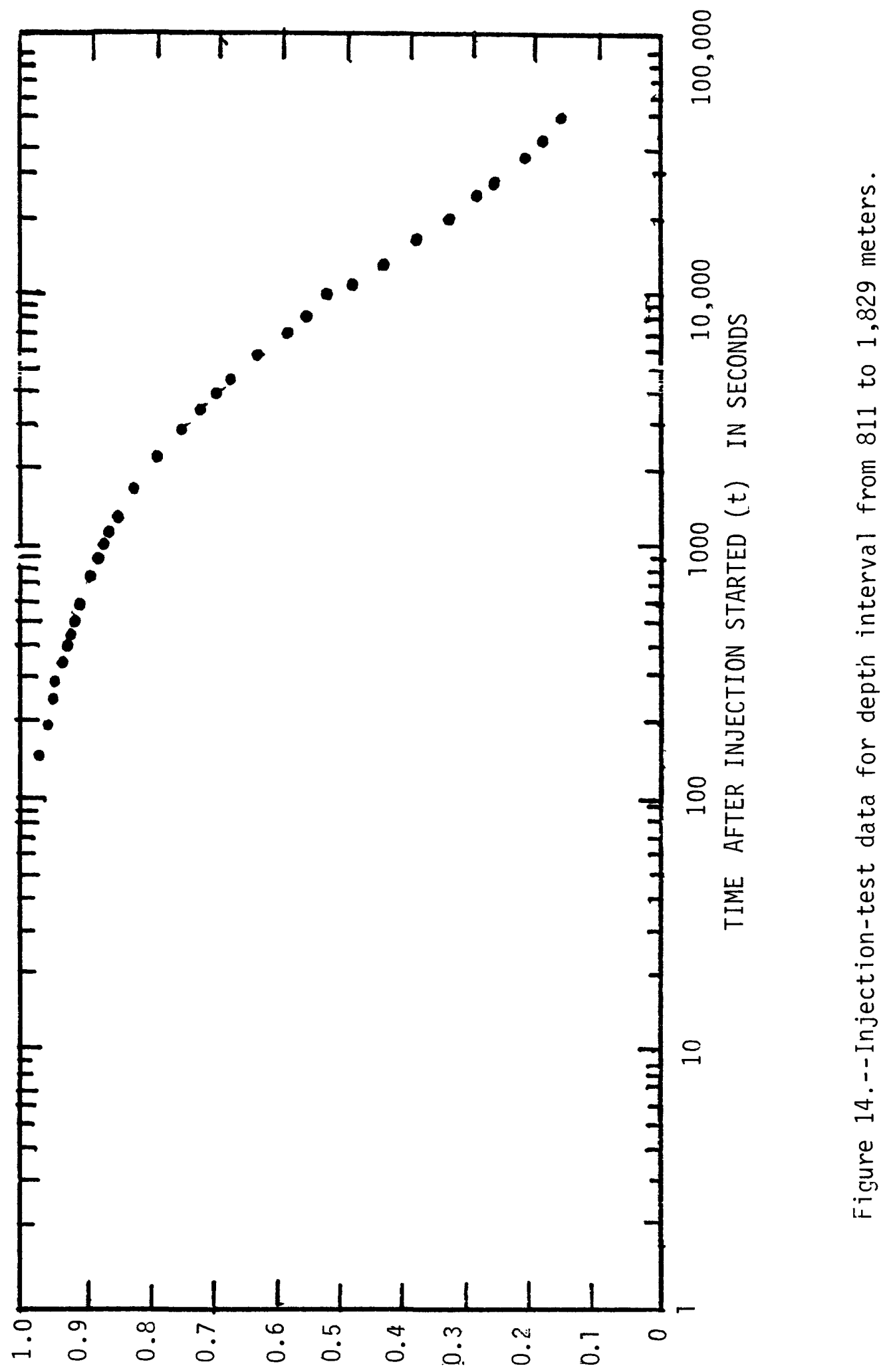

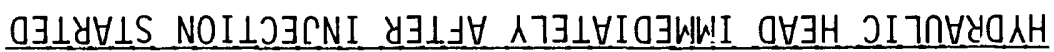

7 ㅂ!I $\perp \forall$ O 


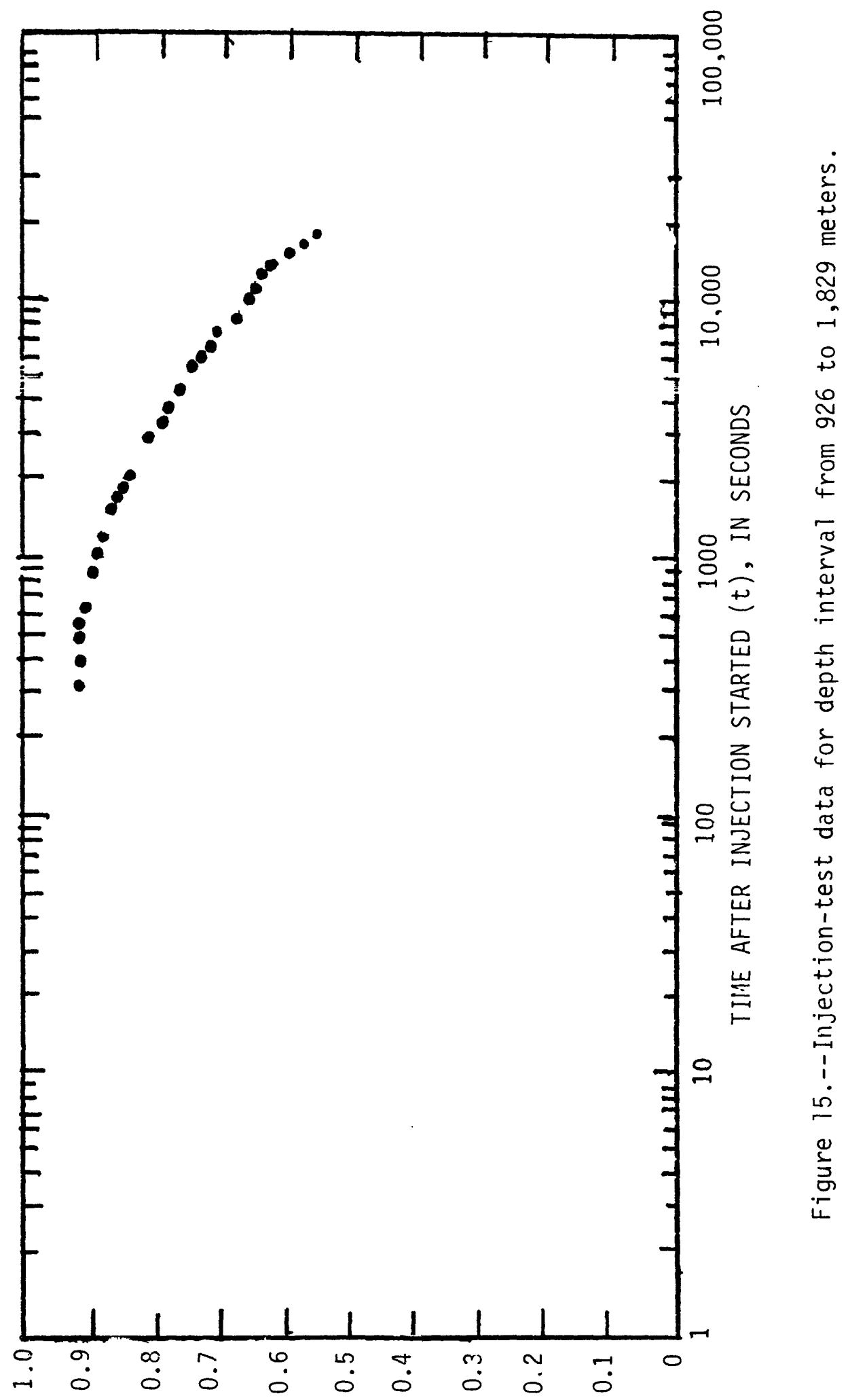

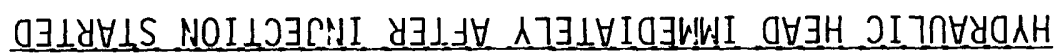

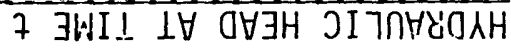




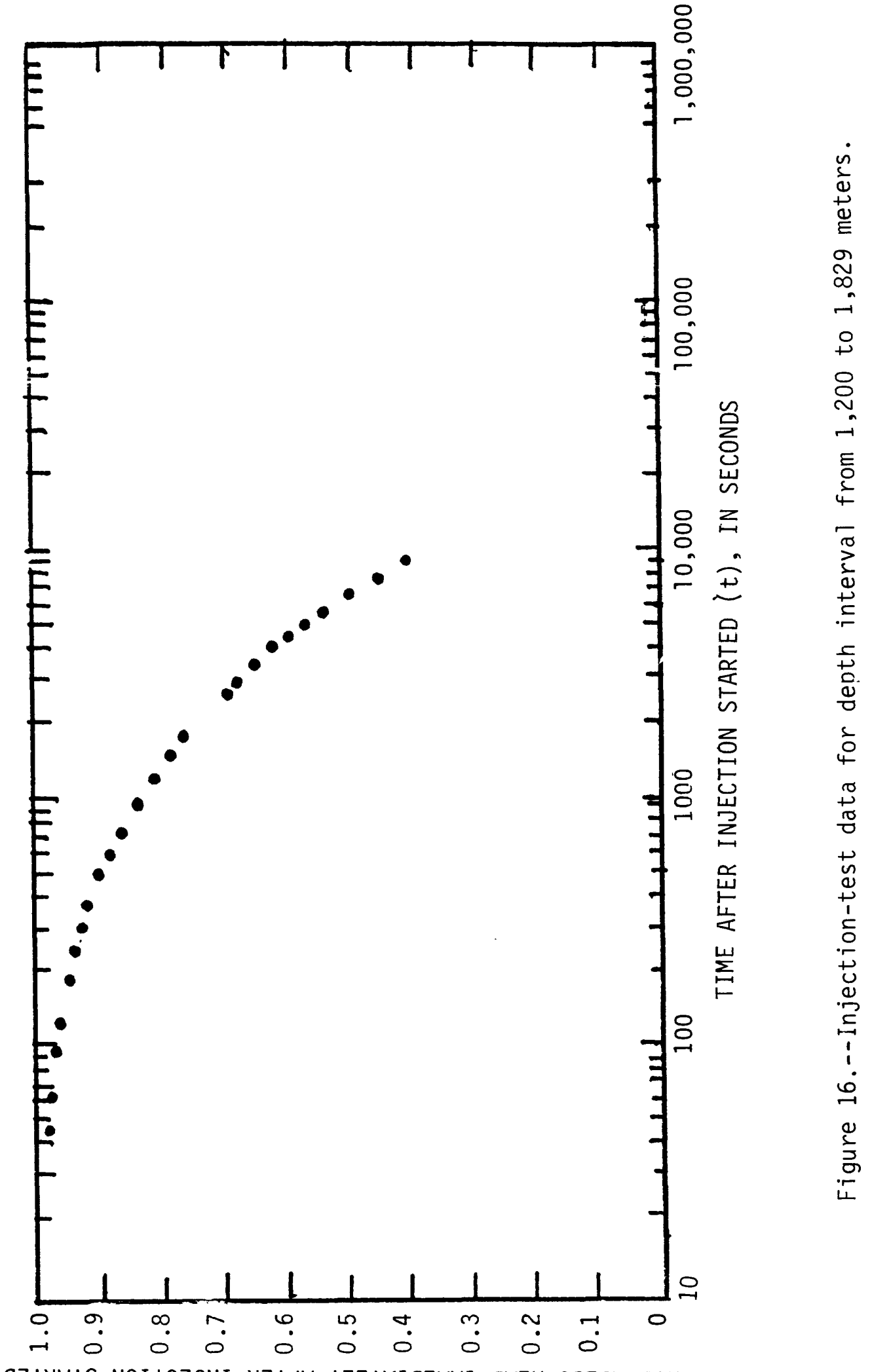

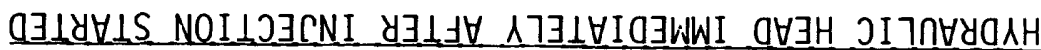

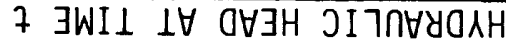




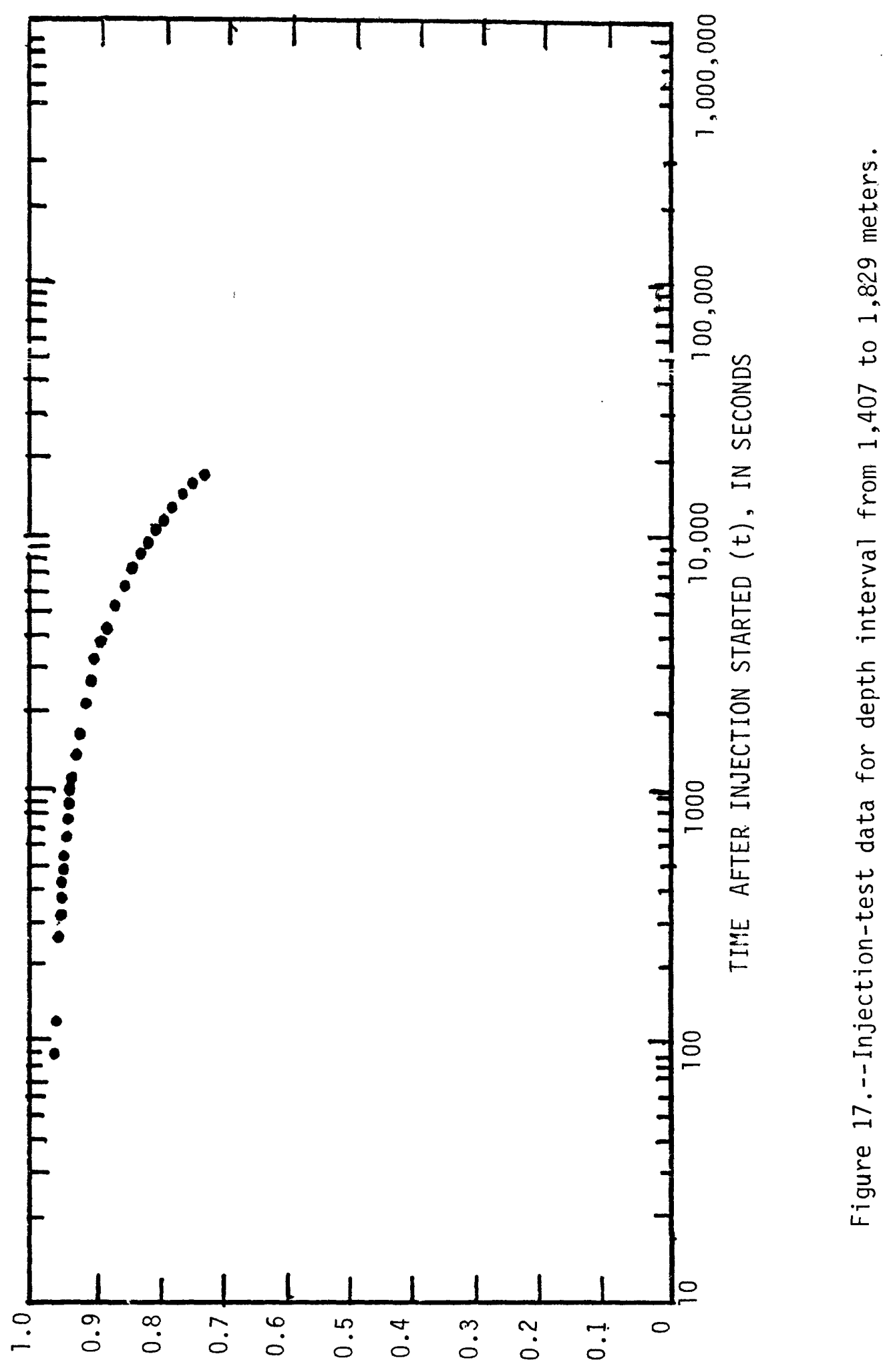

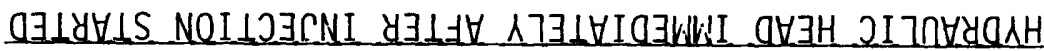

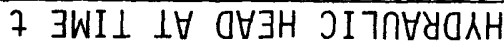




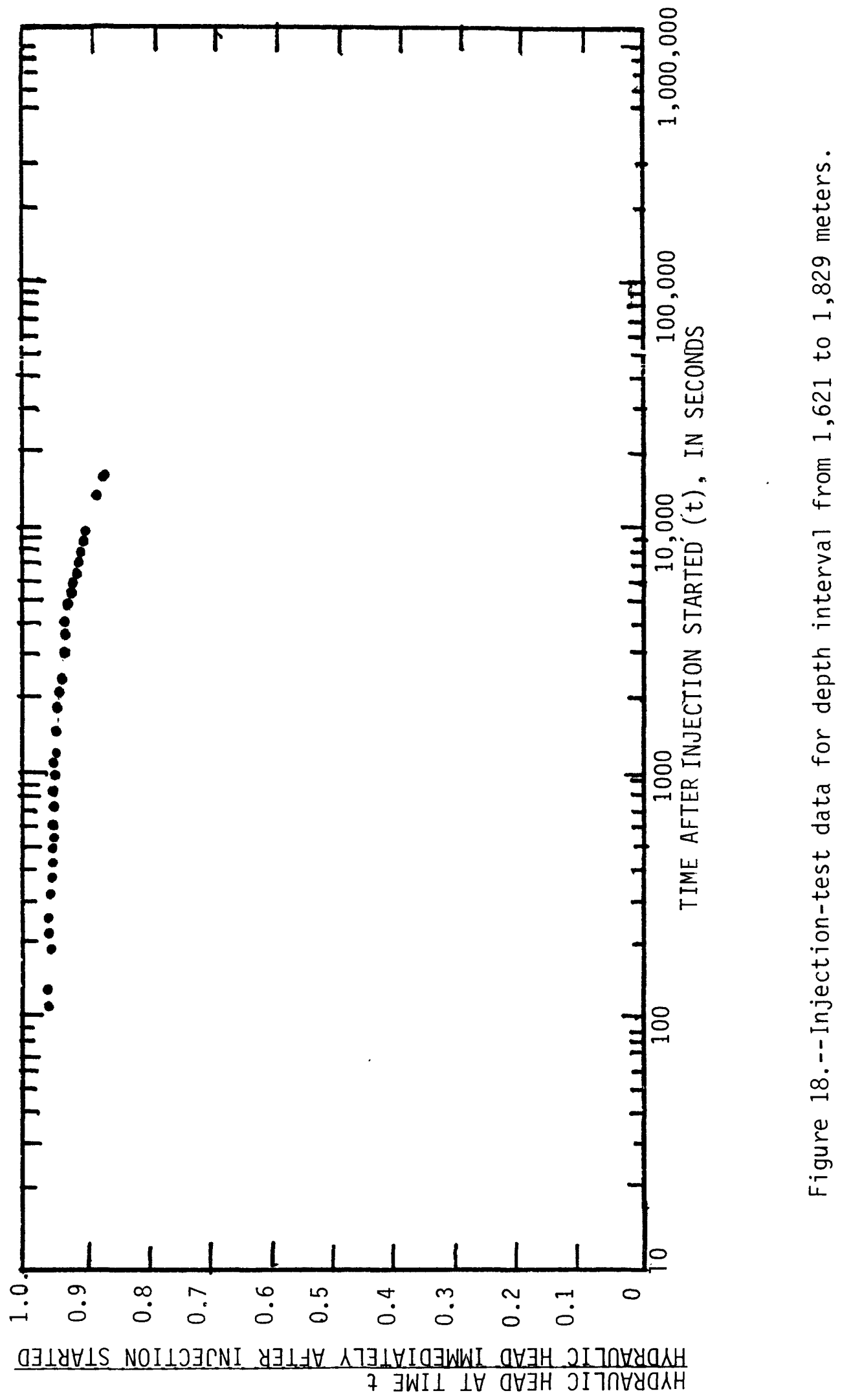


Table 13.--Results of chemical analyses of water samples 1 I

[A11 units are milligrams per liter unless otherwise indicated]

\begin{tabular}{lcc}
\hline Data collected & $\begin{array}{c}\text { Sampled during } \\
\text { pumping of depth } \\
\text { interval from } 572 \\
\text { to } 688 \text { meters }\end{array}$ & $\begin{array}{c}\text { Sampled during } \\
\text { pumping of depth } \\
\text { to } 1,829 \text { meters }\end{array}$ \\
\hline $\begin{array}{c}\text { Volume of water pumped from zone prior } \\
\text { to sampling (1iters) }\end{array}$ & $\underline{10 / 20 / 80}$ & $\underline{12 / 08 / 80}$ \\
580,000 & 420,000
\end{tabular}

Chemical constituents or physical properties

\begin{tabular}{|c|c|c|}
\hline Bicarbonate $\left(\mathrm{HCO}_{3}\right)$ & 122 & 115 \\
\hline Calcium (Ca) & 4.5 & 6.2 \\
\hline Carbon-13/carbon-12 $\left(\delta^{13} \mathrm{C}\right){ }^{2 /}$ & --- & -11.4 \\
\hline Carbon-14 (percent of modern standard) & $19.8 \pm 4$ & $22.4 \pm 1.5$ \\
\hline Chloride (C1) & 5.7 & 5.8 \\
\hline Deuterium-hydrogen $\left(\delta^{2} \mathrm{H}\right) \underline{3 /}$ & -103 & -101 \\
\hline Fluoride (F) & 1.2 & 1.0 \\
\hline Lithium (Li) & 40 & 40 \\
\hline Magnesium (Mg) & 0.0 & 0.0 \\
\hline Oxygen-18/oxygen-16 $\left(\delta^{18} 0\right)^{4 /}$ & -13.4 & -13.5 \\
\hline $\mathrm{pH}$, laboratory & 7.8 & 8.0 \\
\hline $\mathrm{pH}$, field & 7.7 & 7.5 \\
\hline Potassium-40 (picocuries per 1iter) & 1.8 & 1.2 \\
\hline Potassium (K) & 2.4 & 1.6 \\
\hline Residue on evaporation & 176 & 188 \\
\hline Silica $\left(\mathrm{SiO}_{2}\right)$ & 47 & 40 \\
\hline Sodium (Na) & 51 & 51 \\
\hline Specific conductance, field (microseimens) $\underline{5}$ & 255 & 247 \\
\hline $\begin{array}{l}\text { Specific conductance, laboratory } \\
\quad \text { (microsiemens) }\end{array}$ & 258 & 266 \\
\hline Strontium (Sr, micrograms per liter) & 5 & 20 \\
\hline Sulfate $\left(\mathrm{SO}_{4}\right)$ & 18 & 19 \\
\hline Temperature (degrees Celsius) & 33 & 34.7 \\
\hline Tritium (picocuries per liter) & $<20$ & $<20$ \\
\hline
\end{tabular}


Table 13.--Results of chemical analyses of water samples--ContinuedII

\begin{tabular}{ccc}
\hline Data collected & $\begin{array}{c}\text { Sampled during } \\
\text { pumping of depth } \\
\text { interval from } 572 \\
\text { to } 688 \text { meters }\end{array}$ & $\begin{array}{c}\text { Sampled during } \\
\text { interval from } 687 \\
\text { to } 1,829 \text { meters }\end{array}$ \\
\hline & $\underline{10 / 20 / 80}$ & $\underline{12 / 08 / 80}$
\end{tabular}

Chemical constituents or physical properties--Continued

Cations (milliequivalents per liter)

2.50

2.57

Anions (milliequivalents per liter)

2.48

2.61

Difference (percent)

0.55

0.79

$1 /$ Chemical analysis made by U.S. Geological Survey laboratory, Denver, Colorado.

$2 /$ Deviation of carbon-13/carbon-12 ratio of sample from Peedee Belemnite standard ( $P D B)$ relative to $\mathrm{PDB}$, in parts per thousand.

3/ Deviation of deuterium/hydrogen ratio of sample from standard mean ocean water (SMOW) relative to SMOW, in parts per thousand.

$4 /$ Deviation of oxygen-18/oxygen-16 ratio of sample from standard mean ocean water (SMOW) relative to SMOW, in parts per thousand.

5/ Equivalent to micromhos per centimeter at $25^{\circ} \mathrm{C}$. 


\section{SELECTED REFERENCES}

Birdwel1 Division, 1973, Geophysical well log interpretation: Tulsa, Seismograph Service Corporation, Birdwell Division, $188 \mathrm{p}$.

Blankennagel, R. K., 1968, Geophysical logging and hydraulic testing, Pahute Mesa, Nevada Test Site: Ground Water, v. 6, no. 4, p. 24-31.

Schlumberger Limited, 1972, Log interpretation, volume 1--Principles: New York, $113 \mathrm{p}$. 